\title{
A Revogação da Sentença*. (Perfil histórico)
}

\author{
Moacyr Lobo da Costa \\ Professor Adjunto regente de História do \\ Processo Romano, Canônico e Lusitano \\ no Curso de Pos-Graduaçāo
}

\section{Direito Romano II}

SUMÁRIo: 1. A restitutio in integrum como auxilium extraordinarium contra atos civilmente válidos. 2. Tiro Lívio, o SC. de "Asclepiade Sociisque", Terencro e Cícero como fontes literárias para o conhecimento das origens da restitutio in integrum. 3. R.i.i e ius edicendi do Pretor. A codificação do Edito Perpétuo, os casos consagrados de restituição, a cláusula geral de restituição dos maiores. 4. Natureza da r.i.i. A ficção e a fórmula fictícia da actio utiles ex restitutiones. 5. Forma do auxilium extraordinarium concedido pelo Pretor. Decretum e judicium rescissorium. 6. A causae cognitio do Pretor. 7. 0 problema da precedência da r.i.i. ou das ações correspondentes nos casos de medo e de dolo. 8. Prazo para a concessão da r.i.i. 9. Processualização da r.i.i. no sistema da extraordinária cognitio. 10. R.i.i. contra atos do processo e contra a sentença. 11. R.i.i. e appellatio no sistema da extraordinaria cognitio e a recíproca inserção de uma no processo da outra durante o Império. 12. A transformação da r.i.i. sob a Monarquia absoluta. 13. Concessão da r.i.i. em favor da res publica e da Igreja. 14. Nulidade da sentença proferida contra ius constitutionis. 15. A nulidade como inexistência e o emprego da appellatio como gravame de nulidade na nulidade parcial da sentença. 16. A querela como meio autônomo de impugnação de vícios da sentença. 17. A história da r.i.i. e a finalidade do presente trabalho.

1. No regime do Ordo iudiciorum privatorum o Pretor, no exercício de seu direito honorário de auxiliar, suprir ou corrigir o direito civil, a bem da utilidade pública (Dig. 1.1.7.1), podia prometer a concessão de um meio para eliminar os efeitos prejudiciais de atos, ou de negócios jurídicos,

*. Continuação do trabalho publicado no $10^{\circ}$ Fasc. do volume LXXII, de 1977, p. 359 da Revista da Faculdade de Direito. 
que se apresentavam formalmente válidos de acordo com o rigorismo do ius civile, sempre que, a seu critério, houvesse um fundado motivo de eqüidade para justificar a concessão.

Nesses casos a atuação do Pretor assumia a natureza de um auxilium extraordinarium a favor da parte lesada, quando inexistissem outros meios ordinários para impedir as danosas conseqüências daqueles atos civilmente válidos: "nam si communi auxilio et mero iure munitus sit, non debet ei tribui extraordinarium auxilium" (Dig. 4.4.16). A palavra extraordinarium esclarece SCIALOJA ${ }^{1}$ deve ser aqui entendida em duplo sentido: extraordinário é o remédio porque o Pretor não se limita a ordenar o juízo, mas ele próprio assume o conhecimento da controvérsia; extraordinário é também porque se emprega quando faltem todos os outros meios processuais ordinários.

O remédio extraordinário que o Pretor prometia conceder era a restitutio in integrum, que, pela reposição das partes em sua situação anterior, se destinava a desfazer a lesão resultante da rigorosa aplicação dos princípios dos ius civile.

$\mathrm{Na}$ clássica conceituação de SAVIGNY ${ }^{2}$, a restitutio in integrum é a reintegração de um anterior estado jurídico, fundada sobre a contraposição entre a equiidade e o estrito direito, e efetuada graças à potestade pretória que modifica cientemente um direito efetivamente existente.

A importância desse remédio extraordinário era de tal magnitude, que levou um notável romanista ${ }^{3}$ a considerá-lo como uma revolução realizada pela onipotência do Pretor, que se coloca em insurreição contra o direito, de tal modo que, no dizer de HENRI AUBERT ${ }^{4}$, "on est obligé de convenir, que jamais le prêteur ne se montra plus audacieux dans les réformes qu'il apporta au droit civil."

Aliás, os compiladores do Digesto, no Livro Quarto, iniciam o Título Primeiro "De in integrum restitutionibus" com

1. Vitrorio Scialoja, Corbo di Istituzioni di Diritto Romano, Roma 1934, p. 232.

2. F. C. von SAvigny, Sistema del Diritto Romano Attuale, trad. de V. Scialoja, Turim 1896, v. 7, p. 119.

3. Louis Jousserandot, L'Edit Perpetuel, Paris 1883, t. 1, p. 81.

4. HENRI AUBERT, De L'in Integrum Restitutio envisagée comme voie de recours, thèse pour le doctorat, Paris 1884, p. 4. A qualificação da r.i.i. como - meio "le plus audacieux" empregado pelo Pretor, já havia sido usada por GEORgES VidAL, também em tese de doutorado, De la Restitutio in Integrum, Aix 1873, p. 5. - Para J. Declareull, Rome et l'Organisation du Droit, Paris 1924 p. 98, "Rien ne parait, de prime abord, plus arbitraire". 
a reprodução de um texto de ULPIANo que enfatiza: "Utilitas hujus tituli non eget commendatione; ipse enim se ostendit. (Dig. 4.1.1).

Por ser um remédio extraordinário, que se fundava no amplo poder discricionário inerente ao imperium ${ }^{4 a}$, de que estavam investidos determinados magistrados romanos, como o Cônsul, o Pretor, o Pro-Cônsul e o Governador nas províncias, seu emprego não era permitido aos magistrados que não possuiam aquele poder, como os magistrados municipais, segundo informa PAULO: "magistratus municipalibus non permittitur in integrum restituere." (Dig. 50.1.26\$1. ${ }^{\circ}$ ).

2. As origens desse instituto não são bem conhecidas, divergindo os romanistas quanto à época em que teria surgido ${ }^{5}$, bem como quanto à sua conceituação como remédio pretoriano, por não ter sido encontrado qualquer texto ou inscrição que comprove haver sido introduzido em Roma pelo Pretor, e, também, por não ser de sua exclusiva atribuição, competindo igualmente a outros magistrados investidos do imperium, como o Pro-Cônsul e os Governadores nas pro. víncias ${ }^{6}$.

Se é possível, por isso, considerar-se como infundada a afirmação de alguns romanistas mais antigos ${ }^{7}$, de se tratar de instituto de origem pretoriana, por falta de indicação pre-

4a. Sobre o conceito de imperium, ver PaSquale Voci, Per la deffinizione dellimperium nos Studi in memoria di Emilio Albertario, Milão 1953, v. 2, p. 67 e segs.

5. Segundo Girard, a r.i.i. só foi conhecida após a lei "Aebutía", porque antes, não teria aplicação no âmbito do processo das "legis actiones", cf. Histoire de l'Organisation Judiciaire des Romains, Paris 1901, v. 1, único publicado, p. 206. Esse é também o entendimento de CH. LECRIVAIN no verbete "Restitutio in integrum", do Dictionnaire des Antiquités de Daremberg et Saglio, t. 4, p. 848

Em sentido contrário, De Martino, La Giurisdizione nel Diritto Romano, Pádua 1937, p. 119, 120, e G. I. Luzzatto, Procedura Civile Romana, parte III, Bolonha p. 22 e 24, admitem que sua origem seria pré-ebuciana. Esta é a opinião mais difundida modernamente na Itália, como se lê nos verbetes sobre "Restitutio in Integrum" de GIUSEPPE Grosso na Enciclopedia Italiana, v. 29, p. 137; de Gaetano Sciascia no Nuovo Digesto Italiano, v. 18, p. 493; de Giuliano Cervenca, no Novíssimo Digesto Italiano, v. 15, p. 740 .

6. Cf. LUIGI RAGGI, La Restitutio in Integrum, nella cognitio extra-ordinem, Milão 1965, p. 56; Mario Lauria, Iurisdictio nos Studi in Onore di Bonfante, Milão 1930 , v. 2, p. 513, n. $^{\circ} 192$, que considera a qualificação da restitutio como remédio pretório (falsa porque não está demonstrado que o Pretor a tenha introduzido) e metodologicamente errada (porque parece atribuir em exclusivo ao Pretor uma prerrogativa que é de todo magistrado cum imperio.

7. por exemplo: Zimmern, Traité des Actions, trad. de Etiènne, Paris 1843, p. 511; Bonjean, Traité des Actions, Paris 1845, t. 2, p. 440. 
cisa das fontes, o certo e indiscutível é ter sido graças à preponderante atuação do Pretor que a r.i.i. se desenvolveu, assumindo particular relevo na história do processo romano.

Embora de maneira pouco precisa quanto à caracterização do instituto, os textos literários, notadamente algumas narrativas de Tito Lívio, uma comédia de Terêncio e dois discursos de CícERo são as fontes em que tem-se fundamentado as pesquisas sobre a origem e evolução histórica da r.i.i..

Algumas passagens de Tiтo Lívio, examinadas por Charvet ${ }^{\prime}$ e, depois, mais detidamente por SARGenti ${ }^{9}$, revelam que os primeiros casos conhecidos de restitutiones ocorreram nas províncias, por obra do Pro-Cônsul ou do Governador, e, em Roma, por obra do Pretor Peregrino, muito embora sob uma forma embrionária do que viria a ser depois a r.i.i. concedida pelo Pretor, no regime do procedimento formulário.

A origem da r.i.i. não deve ser procurada nas relações entre os citadinos, mas no exercício do imperium dos magistrados nas províncias e, mais tarde, do Pretor Peregrino em Roma. Assim, escreve SARGENTI ${ }^{10}$, não é no quadro dos processos " per legis actiones" que são inseridas aquelas mais vetustas aplicações do instituto, mas no quadro das formas processuais de todo estranhas ao ordenamento jurídico romano, ou daquelas formas que vinham se elaborando graças à atividade jurisdicional dos magistrados nas províncias e do praetor peregrinus em Roma; para afirmar, em seguida, com suficiente certeza, tendo em vista as fontes examinadas, "que a restitutio não nasceu como instrumento para disciplinar relações entre citadinos, mas foi originariamente o fruto da liberdade de poderes de que gozavam os magistrados romanos em face dos estrangeiros e nas províncias."

Segundo esse mesmo autor ${ }^{11}$, na passagem de TITo Lfvio a respeito da decisão do Senado sobre a reclamação apresentada pela embaixada enviada a Roma pelos espartanos, em 183 A.C., contra a condenação imposta pela Liga Aqueana, encontra-se o primeiro exemplo de restitutio que não tem por

8. LouIS CHARVET, Evolution de la Restitution des majeurs en droit privé romain, thèse pour le Doctorat. Grenoble 1920, p. 15 e segs.

9. Manlio Sargenti, Studi sulla "Restitutio in Integrum" no Bullettino dell'Istituto di Diritto Romano, 1966, v. 69, p. 235 e segs.

10. SARGENTI, op. cit. p. 230.

11. SARGENTI, op. cit. p. 248. 
objeto atos de caráter substancial, mas que importa na rescisão de sentenças, pois o Senado decidiu que devem ser rescindidas as sentenças pronunciadas: "restitui iudicia que facta tolli placuit."

Pode-se então sustentar, conclui o citado romanista ${ }^{12}$, que este seja um dos primeiros exemplos, senão o primeiro de seu conhecimento, de um senatusconsulto tendo o escopo preciso de rescindir, com base em critérios de oportunidade política, atos jurídicos validamente praticados e, na espécie, sentenças definitivas.

$\mathrm{Na}$ decisão do Senado a restitutio é vista ainda em sua forma embrionária.

0 primeiro documento jurídico em que a restitutio aparece com claras e precisas conotações substanciais e formais é o senatusconsulto "de Asclepiade sociisque" do ano 78 A.C., segundo afirma SARGENTI ${ }^{13}$ roborado por FABBRINI ${ }^{14}$.

O senatusconsulto "de Asclepiade sociisque" prevê casos de restitutiones motivados pela "absentia rei publicae causa" ${ }^{15}$.

Seu objeto é de recompensar três navarcas gregos, Asclepíade, Polystrato e Menisco, por seu concurso eficaz durante a guerra itálica. Entre as vantagens que o Senado lhes outorgou, umas são simplesmente honoríficas, como o título de "bons cidadãos amigos do povo romano", outras, porém, concedem-lhes direitos como o de reclamar a r.i.i. para desfazer as conseqüências prejudiciais causadas por sua ausência.

Na cuidadosa análise a que submeteu o texto desse senatusconsulto, CHARVET ${ }^{16}$ distinguiu quatro hipóteses susceptíveis de ensejar uma demanda de r.i.i..

A quarta hipótese é particularmente clara e precisa: "sei qua judicia de eis absentibus post quam e patria profecti sunt, facta sunt, ea uti in integrum restituantur et de integro judicium ex senatus consulto fiat".

12. SARgent, op. cit. p. 250.

13. Sargenti, op. cit. p. 251.

14. Fabrizio FabBrini, Per la storia della "Restitutio in Integrum" em "Labeo" Rassegna di Diritto Romano, Napoles 1967, n.o 13, f. 2, p. 208.

15. Sobre o texto do senatusconsulto, ver Pietrangeli, La scoperta di nuove framnemti del senatoconsulto de Asclepiade, no Bullettino dell' Istituto di Diritto Romano, 1948, v. 51-52, p. 281 e segs. O texto primitivo está transcrito em C. J. BRuNs, Fontes Juris romani antiqui, $7^{8}$ ed. Tubingae 1909 , p. 176 a 180.

16. Charvet, op. cit. p. 13. 
Trata-se da promessa inequívoca de rescindir os judicia pronunciados durante a ausência deles, com a faculdade de renovar a instância.

A resolução do Senado em favor de Asclepíade e seus companheiros denota um conhecimento já esclarecido dos prejuízos que a impossibilidade de estar à frente de seu patrimônio pode causar a alguém.

Desde que o dano ocasionado por impedimento justificado revelou a necessidade de uma medida geral de proteção, o Pretor deve ter-se ocupado das mesmas situações que o Senado, fornecendo-lhes então os mesmos remédios.

A semelhança entre as expressões empregadas no senatusconsulto e as constantes do Edito do Pretor a propósito da "reipublicae causa abesset", tal como foi reconstituído posteriormente no Digesto (Dig 4.6.1) demonstra uma visível relação entre os textos, como assinala CHARVET, tanto do ponto de vista da forma quanto do fundo, que não pode ser puramente fortuita.

$\mathrm{E}$, conquanto o senatusconsulto não faça qualquer alusão ao Edito, uma conclusão indiscutível se impõe, a de que nessa época (século I a.C) a r.i.i. era o remédio jurídico utilizado para socorrer aqueles que tivessem sofrido dano em razão da ausência no interesse ou a serviço do povo romano.

Argumenta Charvet que os motivos que levaram o Senado a conceder a r.i.i. em favor de três gregos, levariam o Pretor a utilizar a mesma medida em favor de cidadão romano, nas mesmas circunstâncias.

Por não se conhecer a data do Edito sobre a ausência "reipublicae causa", torna-se impossível apurar-se se ele é anterior ou posterior ao senatusconsulto, mas, segundo as conjecturas de CHARVET ${ }^{17}$, o Edito seria anterior, pois o Senado não apresenta a r.i.i. como uma inovação, mas como medida conhecida, com todas as suas características, que permitem presumir o seu emprego nos anos precedentes.

Entre os textos literários considerados pela generalidade dos autores como fonte para o conhecimento das origens da r.i.i., a passagem do ato II cena IV, verso 9 , da comédia

17. Charvet, op. cit. p. 14 - Sargenti se opõe à opinião de Charvet e argumenta no sentido de demonstrar que os redatores do senatusconsulto não se inspiraram nem modelaram a resolução sobre as disposiçōes do Edito sobre a ausência, que, naquela oportunidade, não estariam já completamente disciplinadas Studi cit. p. 251 segs. 
Phormio de TeRÊncio é, sem dúvida, das mais importantes, por oferecer seguro testemunho de que na época da sua primeira representação (presumivelmente em 161 a.C) a restitutio já era um meio largamente usado, sendo bem conhecido o seu fundamento sobre a aequitas em contraposição ao strictum ius, tanto que podia ser invocada num diálogo teatral que fosse compreendido pelo público ${ }^{18}$.

É muito controvertida a questão do valor que deve ser atribuído às comédias de PlaUTo e de TERÊNCIo como fontes genuínas para o conhecimento dos institutos jurídicos romanos, em face da crítica que se fez a esses dois poetas cômicos, de terem traduzido e adaptado dos modelos gregos as situações descritas em suas comédias, sem lhes acrescentar nada de original ${ }^{19}$.

Assim, segundo DAREST ${ }^{20}$, é escassa a possibilidade de se encontrar naqueles poetas indicações válidas para o conhecimento do direito romano de sua época, visto como as questões jurídicas localizadas em suas comédias eram antes de direito ático que de direito romano, de onde a recusa de considerá-las como fontes literárias do direito romano.

Em contraposição a esse entendimento, outros estudiosos que se deram ao trabalho de analisar detida e exautivamente todas as passagens das comédias de Plauto e de Terêncio, em que são apresentados problemas de direito, como Emílio COSTA ${ }^{21}$ e BEKKER ${ }^{22}$, chegaram à conclusão de se tratar de institutos do direito romano, os que aqueles poetas referiam, inclusive com os termos adequados para ressaltar, de maneira inteligível para o auditório, as situações cômicas descritas.

18. РновмIо, II, IV, 9 .. "Mihi

Sic hoc videtur: quod Te ABSENTE hic filius

Egit, Restitui in INTEGRUm aequum est et bonum

Et id impetrabis"...

19. Cf. P. KRUEGER, Histoire des Sources du Droit Romain, trad. de Brissàud, Paris 1894, p. 102. DE TERENCIo disse que ele "se rattache si étroitement à ses modéles qu'il y a bien peu de chose à tirer de son oeuvre pour l'étude du droit romain"

20. Rodolphe Dareste, Études d'histoire $d u$ droit, $2 \mathrm{e}$ série, $2^{\mathrm{e}}$ ed., Paris 1926 , p. 149 e segs. "Pode-se por como regra geral que "quand Plaute parle de droit c'est de droit grec qu'il s'agit, alors même qu'il emploie des termes latins" p. 163.

21. Emílio Costa, Il diritto privato romano nelle comedie di Plauto, Turim 1890, e Il diritto privato nelle comedie di Terenzio, em Archivio Giuridico, 1893, v. 50, p. 407.

22. E. I. BeKKER, Die römischen Komiker als Rechtszeugen, em Zeitschrift der Savigny - Stiftung 1892, v. XIII, citado por E. Costa, op. cit. p. 410. 
Ultimamente, depois de cuidadoso estudo dessa interessante questão, em face das conhecidas e radicais opiniões divergentes, o emérito PAOLI ${ }^{23}$ indica uma nova solução segundo o seguinte critério metodológico. Os cômicos latinos servem como fonte de informação para o direito ático ou para o direito romano, só quando um prudente trabalho de análise nos tenha conduzido a estabelecer em qual dos dois ordenamentos jurídicos o elemento individuado possa ser colocado. No momento em que um dado de informação possa ser igualmente colocado no direito grego e no direito romano, "la tirannide del non liquet consiglierá di non farne uso nè in un senso nè nell'altro".

Quanto à celebrada passagem do Phormio, que GIRARD ${ }^{24}$ entendeu não se referir ao instituto romano da r.i.i., o qual, a seu ver, só teria surgido após a lei Aebutia, a opinião predominante entre os romanistas ${ }^{25}$ é no sentido de considerar o verso de TERÊNCIO como inequívoco testemunho de que a r.i.i. era conhecida e praticada pelos magistrados romanos na segunda metade do século II a.C., muito embora, como ressaltou a doutora KORNHARDT ${ }^{26}$, no mais recente trabalho monográfico dedicado ao assunto, a ação da comédia se desenrole na Grécia, pois TERÊNCIO descreveu na cena uma situação de estilo puramente romano.

Ademais, como salientou SARGENTI ${ }^{27}$, na apreciação do estudo da doutora KORNHARDT, não se pode negar que reflitam a concepção e a terminologia de restitutio os dois versos:

$$
\text { "restitui in integrum aequum est et bonum; }
$$

23. Ugo Enrico Paol, Comici latini e diritto attico, Milão 1962, p. 69.

24. P. F. GIRARD, Histoire de l'Organisation, cit. p. 206, nota 1.

25. F. GLUCK, Commentario alle Pandette, livro IV, trad. de Landucci, Milão 1890, § 467 p. 211; M. VITA LEVI, De Restitutione in Integrum, Dissertatio, Augustae Taurinorum mDccclxxxi, p. 34; L. CHaRvet, Evolution, cit. p. 20; G. Cervenca, Per lo studio della "Restitutio in Integrum" em Studi in Onore di Biondo Biondi, Milão 1965, v. 1, p. 604 e Studi Vari sulla "Restitutio in Integrum" Milão 1965, p. 5, nota 8; L. RAGGI, La "Restitutio in Integrum"。 cit. p. 284, nota 46; para EDOUARD CUQ o texto de TERENcio não prova a existência do Edito sobre a restituição dos ausentes, mas demonstra que a idéia de uma reação contra o rigor do direito civil, sob a forma de restituição, era discutida nessa época - Manuel des Institutions Juridiques des Romains, $2 .^{\circ}$ ed., Paris 1928, p. 833 , nota 1 .

26. H. KORNHARDT, Restitutio in Integrum bei Terenz, in Thesaurismata Festschrift fur Ida Kapp, Munchen 1954, p. 65, citado por Sargenti, op. cit. p. 232 .

27. SARGENTI, op. cit. p. 233. 
Uma vez que TERÊNCIO alude à restitutio relativamente ao matrimônio, coisa absurda para os romanos, parece residir nessa aburdidade o relevo cômico da passagem, consoante plausível interpretação ${ }^{28}$.

Sob o ponto de vista cronológico, pretende a doutora KORNHARDT que a r.i.i., referida por TERÊNCIO na comédia que foi representada em Roma pela primeira vez em 161 a.C., teria sido introduzida pouco tempo antes, por obra de SCIPIÃo NASICA, amigo de TERÊNCIo, que foi Pretor Urbano em 165 a.C. Mas, como ponderou FABBRINI ${ }^{29}$, não é possível com base nesse único testemunho pretender datar com exatidão o aparecimento da r.i.i. em Roma.

Ao ver de SARgenti ${ }^{30}$, o uso da r.i.i. não é de ser considerado como novidade introduzida por um magistrado inovador e helenizante, na época em que TERÊNCIO escrevia e fazia representar o Phormio, mas deve ser procurado em uma praxe assaz mais antiga, expressão do imperium do magistrado e dos poderes de governo do Senado, que se exercia sobretudo nas relações com os súditos nas províncias.

Segundo outros autores ${ }^{31}$, a r.i.i. a que se refere TERÊNCIO, teria sido criação do Pretor PUblicio, considerando ViTA LeVI ${ }^{32}$ que esta era a mais provável das opiniões, "illorum probalior opinio"; todavia, a época certa daquele evento não foi jamais comprovada, permanecendo no terreno das conjecturas.

Quanto aos escritos de Cícero, muito embora o grande orador não nomeie qualquer Edito urbano, que parece desconhecer, e, suas referências sejam todas a situações ocorridas nas províncias, ou envolvendo habitantes delas, é nas suas orações, particularmente, na segunda contra VERRES e na oração Pro Flacco, que se encontram as mais importantes notícias sobre a existência da r.i.i. na idade republicana, consoante o entendimento generalizado entre os estudiosos antigos e contemporâneos ${ }^{33}$.

28. SARgenti, op. cit. p. 231; Fabbrini, Per la storia, cit. p. 206.

29. FABBRINI, op. cit. p. 206, nota 26.

30. Sargenti, op. cit. p. 235; no mesmo sentido Charverr, op. cit. p. 123.

31. É a opinião de Gluck, op. cit. p. 211, com apoio em C. G. BIENER, Historia iuris civilis de restitutionibus in integrum, Lipsiae 1779, cap. v. p. 22.

32. VITA LEVI, De restitutione, cit. p. 34.

33. Cf. ARMand Gasquy, Cicéron Jurisconsulte, avec une table des principaux passages relatifs au droit, Paris 1887, p. 299; Emílio Costa, Cicerone Giureconsulto, Bolonha 1928, v. 1, p. 94 e segs. e v. 2, p. 41-42; Charvet, op. cit,. p. 8 e segs.; SARGenti, op. cit., p. 261-284; FABbrini, op. cit., p. 209. Para estudo mais 
Nessas duas orações CícERo refere o largo emprego das restitutiones por magistrados romanos nas províncias, como instrumento jurídico fundado no seu poder de imperium, em cujas decisões transparece o senso político daquelas autoridades empenhadas em desfazer os danos resultantes de atos contrários à eqüidade, para captar a confiança e o apoio dos habitantes das regiões conquistadas.

Em todas essas restitutiones, conquanto enquadrem-se no campo da atividade discricionária dos magistrados provinciais, CÍcERo não deixa entrever, contudo, uma figura específica da restitutio in integrum que se possa classificar entre as que se conservaram posteriormente nos Editos dos Pretores.

As restitutiones descritas naquelas orações revelam, quando muito, uma fase, por assim dizer, ainda fluída do instituto, observa SARGENTI ${ }^{34}$, que será mais tarde superada mediante a regulamentação edital e a elaboração de suas cláusulas no edito, por obra da jurisprudência.

E verossímel supor, então, em face dessas fontes literárias, que, a partir do momento em que seus poderes se ampliam, no primeiro quartel do VIr século de Roma, o magistrado urbano tenha se empenhado em rescindir atos contrários à eqüidade, embora válidos segundo o ius civile, importando para a $\mathrm{Me}$ trópole um instituto jurídico que estava sendo utilizado nas províncias, tal como, no mesmo período, o legislador se inspirava nas práticas processuais que vinham sendo observadas nas províncias, nos iudicia com os peregrinos, para modificar o vetusto sistema processual das ações da lei ${ }^{35}$.

3. No começo o Pretor Urbano, fundado na amplitude do poder de imperium, interpunha sua autoridade para fazer restabelecer uma situação jurídica, mediante o emprego daquele auxilium extraordinarium importado dos magistrados provinciais, caso por caso, segundo sua livre discricionariedade na apreciação prévia das circunstâncias de fato expostas pelo interessado.

Além do critério abstrato e genérico da aequitas, não existia norma para disciplinar a concessão da restitutio.

aprofundado do assunto, ver a fundamental monografia de DuQuesne, Cicéron, Pro Flacco c. 30-32, et l'in integrum restitutio, Annales de l'Université de Grenoble, 1908, v. XX; também Massimo BRUTti, La Problematica del dolo processuale nell' esperienza romana, Milão 1973 , v. II. p. 341-356.

34. SARgenti, op. cit. p. 265.

35. Nesse sentido, Charvet op. cit. p. 24, com a concordância de Cervenca, Per lo studio, cit., p. 604, nota 9. 
Com o correr dos anos tornaram-se conhecidos os casos para os quais havia sido concedida, e, em conseqüência, foram delineando-se os casos-tipo que o Pretor passa a acolher em seu Edito, ao assumir a pretura, formulando as correspondentes promessas gerais de concessão da r.i.i.

Por essa forma vão fixando-se os casos em que se concretizam as hipóteses previstas nos Editos, e o direito honorário do Pretor, de reparar a lesão resultante do rigorismo do ius civile, atinge seu ponto culminante no regime do processo formular, na República e no I século do Principado.

Embora não fosse obrigatório, era costume do Pretor, em homenagem à tradição respeitada pelo espírito romano, incluir no seu Edito, quase que integralmente, as promessas de tutela de direito asseguradas na pretura anterior, consagradas pelo uso e aprovadas pela opinião pública, mudando apenas aquilo que tivesse sido desaprovado e acrescentando $o$ que lhe parecesse vir ao encontro das necessidades jurídicas dos cidadãos, em razão do desenvolvimento da Urbs, com o que, a maior parte do Edito ânuo torna-se edictum tralaticium, que passava imutável de Pretor a Pretor.

No decurso do último século da República, a autoridade do Pretor se consolida como supremo magistrado para os assuntos da justiça, levando o direito honorário, mediante o regular exercício do ius edicendi, a suplantar o ius civile, ensejando, assim, a formação de extensa jurisprudência a propósito das inúmeras criações do direito pretoriano, notadamente do emprego da r.i.i. como auxilium extraordinarium.

Mas, em decorrência do ius edicendi, os Pretores, no curso da pretura, se permitiam editar outros, chamados de edicta repentina, que modificavam cláusulas do Edito geral, publicado no Album no início de sua magistratura, ocasionando vascilações e incertezas na aplicação do direito pretoriano.

Já no Império, entre os anos 125 e 128 d.C., segundo alguns ${ }^{36}$, ou 130 e 134 segundo outros ${ }^{37}$, ADRIANo incumbiu SAlVio JUliano, considerado como o maior jurisconsulto da época, de reunir e condensar num único Edito o material disperso no sem-número de Editos conhecidos, com a finali-

36. Sobre a data e as circunstâncias da codificação do Edito por SALvio Juliano, consultem-se Girard, Mélanges de Droit Romain, Paris 1912, v. 1, pp. 214 e 248, e Charvet, op. cit., p. 26.

37. Arangio-Ruiz, Storia del Diritto Romano, 5. a ed. Napoles 1947, p. 154. 
dade de codificar o direito pretoriano e tornar segura sua observância na organização dos juízos.

Concluído o trabalho de SALvio Juliano, ADRIANo submeteu-o ao Senado e provocou sua aprovação por um senatusconsulto, com o que é atribuído força de lei à codificação edital que passa a se chamar Edito Perpétuo.

Justiniano, nas famosas constituições Tanta e Dedit, que tratam da confirmação do Digesto, fornece precisas informações a esse respeito. Na Constituição Tanta, § 18: "Et hoc non primum a nobis dictum est, sed ab antiqua descendit prosapia, quum et ipse Julianus, legum et edicti perpetui subtilissimus conditor, in suis libris hoc retulit, ut, si quid imperfectum inveniatur, ab imperiale sanctione hoc repleatur; et non ipse solus, sed et divus Hadrianus in compositione edicti et senatuconsulto, quod eam secutum est, hoc apertissime definivit, ut, si quid in edicto positum non inveniatur, hoc ad eius regulas ejusque coniecturas et imitationes possit nova instruere auctoritas."

E na Constituição Dedit, § 18: "et hoc, non solum a nobis dictum est, verum janpridem etiam omnium, qui inter jurisconsultos floruerunt, doctissimus Julianus id ipsum apparet dixisse, et ab imperiali auctoritate super exortis controversiis implorasse supplementum, et insuper Hadrianus piae memoriae, quique Praetorum annua edicta in brevem quemdam coegit tractatum, optimum Juliannum ad hoc assumens, in oratione, quam in publico recitavit in veteri Roma, hoc ipsum asserit, quod si quid praeter id, quod constitutum est, emerserit, officium sit eorum, qui in magistratu sunt, id conari dirimere, et remedium adhibere secundum eorum, quae jam disposita sunt, consequentiam ${ }^{38 . "}$

O fato histórico da codificação edital, realizada por SALvio JULIANO, por incumbência do imperador ADRIANO, mencionado expressamente por JUSTINIANo em duas Constituições e referido em fontes literárias anteriores ao período justinianeu,

38. Na tradução de Alvaro D'Ors, Const. TANTA, § 18: "Y esto no somos nos quienes lo decimos por primera vez, sino que tiene un viejo precedente, ya que el mismo Juliano, agudíssimo jurisconsulto y auctor del Edicto Perpetuo, lo dice asi en sus proprias abras: que se algo resulta incompleto, se colme con la sanción imperial; y no sólo él, sino también Adriano, de consagrada memoria, al redactarse el Edicto y en el consecutivo senado consulto, asi lo definió con. toda claridad: que si se encontraba algo no previsto en el Edicto, lo pudiera disponer la nueva autoridad conforme a las reglas, principios y analogias del Edicto". 
como EUtrópio e AURELIUs ViCTOR no IV século e SÃo JERôNIMo no princípio do V século, tem sido admitido pela generalidade dos romanistas ${ }^{39}$, com a conhecida exceção representada pela opinião contrária de ANTONIo GUARINo $\stackrel{40}{\text {, para }}$ quem a codificação de SAlvio Juliano jamais teria se realizado, não passando de uma lenda surgida no período postclássico, a partir do IV século, a história do Edito Perpétuo Juliano-Adrianeu.

O texto original da codificação não é conhecido, por não ter sobrevivido à reforma legislativa de JUSTINIANo, sendo certo, contudo, que o mesmo era utilizado para o ensino do direito no segundo ano de aprendizagem, como informa o Imperador na Constituição "Omnem reipublicae", que a ele ainda se referiu na Constituição "Dedit" como "brevi libello", a demonstrar que o conhecia.

Const. DEDIT, \& 18: "y no decimos esto solo como cosa nuestra, sino que ya Juliano, el mas sabio de los jurisconsultos famosos, se ve que decia lo mismo, al pedir para las questiones que se presentabam por primeira vez el complemento de la realeza; y por su lado, Adriano, de consagrada memoria, a compilar en un breve libro las leyes anuales de los pretores, dando a Juliano la dirección de dicha obra, dijo lo mismo en el discurso que pronunció publicamente en antigua Roma; que si ocurria algo que no estuviera previsto, era conveniente que los magistrados procuraram definirlo conforme a la analogia de lo ya legislado" - El Digesto de Justiniano, Pamplona 1968, t. I, pp. 28 e 35.

39. Cfs. PaUl KRUEGer, Histoire des Sources du Droit Romain, trad. Brissaud, Paris 1894, p. 115 a 117; ConTARdo FERRINI, Storia delle Fonti del Diritto Romano, Milão 1885, p. 93; Emílio Costa, Storia delle Fonti del Diritto Romano, Turim 1909, p. 90, 91; SALvatore Riccobono, Lineamenti della Storia delle Fonti e del Diritto Romano, Milão 1949, p. 70; FRITZ SchulTz, History of Roman Legal Science, Oxford 1946, p. 127; Padellettr-Cogliolo, Storia del Diritto Romano, $2 .^{\mathrm{a}}$ ed. Florença 1886, p. 401 e 408, nota 4; PrETro Bonfante, Storia del Diritto Romano, 4. ${ }^{\mathrm{a}}$ ed. Roma 1934, v. I, p. 359; ARANGro-RuIZ, Storia del Diritto Roma-

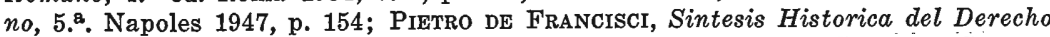
Romano, ed. Rev. de Derecho Privado, Madri 1954, p. 409, 410; Giuseppe Grosso, Lezioni di Storia del Diritto Romano, 5. ${ }^{\text {a }}$ ed., Turim 1965, p. 382; Sílvio MeIrA, História e Fontes do Direito Romano, São Paulo 1966, p. 136.

40. Antônio Guarino, L'Esaurimento del iūs honorarium e la pretesa codificazione dell'Editto, nos Studi in memoria di Emilio Albertario, Milão 1953, v. I, p. 625 e segs. especialmente p. 627. Do mesmo autor, Storia del Diritto Romano, $5{ }^{\text {a }}$ ed. Napoles 1975, p. 431 e L'Esegese delle Fonti del Diritto Romano. Napoles 1968 , v. I, p. 401.

A opinião de GUARINo foi frontalmente refutada por Adolfo Berger, no artigo Due note su Salvio Giuliano, publicado no mesmo volume dos Studi Albertario, p. 605. A opinião contrária de GUARINo é referida por WoLFGANG KUNKEL, História del Derecho Romano, trad. de J. Miquel. Barcelona 1970, p. 103, nota 42, por Carlo A. Maschi, Il Diritto Romano, La Prospectiva Storica, 2. ${ }^{a}$ ed. Milão 1966, p. 97, nota 9, por G. Grosso, Lezioni di Storia, cit. p. 382, nota 2. 
O Edito Perpétuo domina toda a história do direito pretoriano ${ }^{41}$ e encerra um grande capítulo na história da jurisprudência romana ${ }^{42}$.

O Edito foi comentado pelos jurisconsultos Gaio, UluPIANo e PaUlo, de cujos comentários os organizadores do Digesto transcreveram os trechos que reproduziram, o que possibilitou, mais tarde, o notável empreendimento de se tentar a reconstituição da ordem do texto original de JULIANo. A essa tarefa se dedicaram vários romanistas, a partir do século XVI, cujos trabalhos, entretanto, foram considerados insatisfatórios pela crítica posterior ${ }^{42 a}$.

Por extraordinária coincidência, no ano de 1883 são impressos, concomitantemente, na Alemanha e na Suissa, os dois grandes livros de OTTO LENEL ${ }^{43}$ e de LOUIS JOUSSERANDOT ${ }^{44}$, que conquistaram a reputação de terem atingido o objetivo da ambicionada reconstituição.

Não são poucas, nem pequenas, as diferenças entre esses dois livros, particularmente, quanto à ordem da divisão e distribuição da matéria.

JOUSSERANDOT, a exemplo do plano seguido por RUDORFF ${ }^{44 a}$, divide o Edito em 2 partes, com 4 livros, com vários títulos, cada título com vários parágrafos com as correspondentes denominações.

LENEL ${ }^{45}$, que criticara seriamente o plano da reconstituição de RUDORFF, por entender que o autor do Edito não teria tido em vista realizar um trabalho simétrico de sistematização, segundo as concepções modernas, mas de codificar as normas editais, tal como se apresentavam nos diferentes Editos, adotou o plano mais simples de considerar que o Edito Perpétuo comportava quatro divisões capitais, em cada uma das quais

41. Ernest Glasson, Étude sur Gaius, Paris 1885, p. 258.

42. F. Schulz, History, cit. p. 127.

42a. Ver a indicação desses autores feita por Glasson, op. cit. p. 272. Entre os trabalhos desses autores gozou de maior apreço a restituição realizada por RANChiN, professor da Universidade de Montpellier, em 1597; cf. Glasson, loc. cit; Louis Jousserandot, L'Édit Perpetuel, t. I, p. XXVIII.

43. Otтo Lenel, Essai de reconstitution de l'Edit Perpetuel, trad. de F. Peltier, 2 vols., Paris 1901-1903, do original Das Edictum perpetuo ein Versuch zu dessen Wiederhrstellung, Leipzig, 1883.

44. Louis Jousserandot, L'Édit Perpetuel Restituté et commenté, 2 vols. 1883, impressos em Genebra e editados por A. Maresq Ainé, Paris.

44a. ADOLPH F. RUDORFF, De juris dictione edictum, edicti perpetui quae relinqua sunt, constituit, adnotavit, edidit, Lipsiae, apud S. Hirzelium 1869.

45. Otтo Lenel, op. cit., p. 16, 17. 
a matéria estava ordenada em títulos e os títulos em parágrafos, com as correspondentes denominações, mas, tanto os títulos como os parágrafos obedecendo à ordem seguida da numeração. Assim, segundo a reconstituição apresentada por LENEL, o E.P. teria 45 títulos com 292 parágrafos, não contando os 3 títulos e 4 parágrafos do Edictum Aedilium Curulium que vem em apêndice.

A reconstituição de LENEL grangeou elogios dos romanistas que a adotaram em suas obras ${ }^{46}$.

$\mathrm{Na}$ reconstituição de JOUSSERANDOT ${ }^{4 i}$ a matéria que diz respeito à restitutio está colocada na Pars Prima, liber I, Titulus IV "De in Integrum Restitutionibus" com 7 parágrafos: § 1.0 "De Metu"; § 2 "De Dolo malo"; 33 " De Minoribus viginti quinque annis"; $\$ 4$ "De Capitis diminutione"; $\S 5$ "Ex quibus causis majores viginti quinque annis in integrum restituuntur", § 6 "De eo quod falso tutore gestum erit"; § 7 "De alienatione judici mutandi causa."

Na obra de LENEL 48 , a matéria se encontra no Título X, "De in Integrum Restitutionibus", com 9 parágrafos: $\$ 39$ "Quod metus causa gestum erit", § 40 "De dolo malo"; § 41 "De minoribus viginti quinque annis"; § 42 "De capitis minutis"; § 43 "Quod falso tutore auctore gestum(?) esse dicatur"; § 44 "Ex quibus causis maiores viginti quinque annis in integrum restituuntur"; $\$ 45$ "De litibus restituendis"; $\$ 46$ "De alienatione iudicii mutandi causa facta"; $\$ 47$ "De restitutione heredum?"

Dos casos - tipos recolhidos no Edito Perpétuo, segundo a reconstituição proposta a partir dos comentários de ULPIANo, o de maior abrangência era o previsto no Título $\mathrm{X}, \S 44$, "Ex quibus causis maiores viginti quinque annis in integrum restituuntur" ${ }^{49}$, que os compiladores do Digesto reproduziram no Livro IV, Título VI, § $10^{050}$.

46. Ferrini, Storia delle Fonti, cit. p. 95, 98; Schulz, History, cit. p. 149; Bonfante, Storia cit., v. 2, p. 248-271; Sílvio Meira, História, cit. p. 143.

47. JoUSSERANDOT, op. cit., v. 2, p. 574-579; ver a exposição e comentários no v., 1 , p. 80-117.

48. Lenel, op. cit.., v. $1, \mathrm{p} \mathrm{XX}$, e a exposição e comentários no mesmo volume, $p$ 127-146.

49. LENEL, op. cit., v. 1, p. 137.

50. O texto do Digesto é o seguinte:

- "Nadie dejará de reconocer que es justísima la razón de este edicto; porque con él se repara el derecho lesionado durante el tiempo en el que alguien se hallaba ocupado en algún asunto público o sufria las consecuencias de un suceso adverso, y se da remedio también contra éstos, para que lo que sucedió 
Nesse Edito, que se pretende tenha tido por Autor o Pretor PUBLÍcio, estavam previstos os diferentes casos em que alguém tenha sido lesado em seus direitos ou sofrido prejuízo em seus bens, quando se encontrava ausente.

$\mathrm{Na}$ cláusula final, conhecida por cláusula geral, o Edito ampliava o poder de concessão do auxilium extraordinarium, sempre que ao Pretor parecesse haver alguma outra causa justa, porque podiam apresentar-se outros casos que poderiam dar lugar à restituição, sem que tivesse sido possível prevê-los.

O que o Edito quer é que se venha em socorro de todos aqueles que estão ausentes por necessidade e não voluntariamente ${ }^{51}$, como disse ULPIANo: "et generaliter quotiescumque quis ex necessitate non ex voluntate abfuit, dici oportet ei subveniendum" (Dig. 4.6. 26 §).

Quanto à referência às leges, plebiscita, senatusconsulta, edicta, decreta principum, devia entender-se que a r.i.i. seria concedida pelo Pretor naqueles outros casos, não se tais diplomas legais o permitissem, mas se não se opusessem ${ }^{51 a}$ "Quae clausula non illud pollicetur, restituturum, si leges permittant; sed si leges non prohibeant". (Dig. 4, 6. 28 § 2).

A disposição da chamada cláusula geral é do maior interesse para o esclarecimento de um relevante problema histórico, proposto por alguns romanistas, em razão da codificação do Edito Perpétuo: o da limitação do ius edicendi do Pretor.

A política do imperador ADRIANo, no tocante à ordem judiciária, foi no sentido de assegurar a supremacia imperial

ni les dañe ni tampoco les aproveche. Las palabras del edicto son las síguientes: "Si se hubiese causado algún daño en los bienes de alguién, cuando éste se hallase ausente por miedo, o por asunto público sin dolo malo, o estuviese preso, retenido en esclavitud o en poder de los enemigos; en el caso de que contra alguno de ellos se dijese que (con posteríoridad) habia prescrito su acción; asimismo, si otro hubiese adquirido por usucapión alguna cosa, o hubiese recuperado la que se perdió por falta de uso, o se hubiese liberado de alguna acción porque hubiese prescrito o porque el ausente non se defendiese, o porque estuviese preso, 0 porque no se prestara a ser demandado, o porque no fuese lícito demandarlo contra su voluntad, siempre que se hubiese recurrido al magistrado sobre este asunto; o si se denunciase que el magistrado habia privado a alguién de alguna acción sin dolo malo del mismo; en todos estos casos daré una acción dentro del año en que hubiese posibilidad de reclamar; asimismo; si me pareciese haber alguna otra justa causa, concederé la restitución total sobre lo que en la misma fuese lícito conforme a las leyes, plebiscitos, senadoconsultos, editos y decretos de los principes" - trad. de A. D'Ors, El Digesto, cit. p. 210.

51. JousSERANDOT, op. cit. v. 1, p. 106.

51a. Vita Levi, De Restitutione in Integrum, cit p. 40. 
nos dois importantes sectores. do ius respondendi e do ius edicendi.

Quanto ao ius respondendi, o Imperador aumentou consideravelmente o prestígio dos jurisconsultos oficiais, ou seja, daqueles que haviam obtido do Imperador aquele direito, decidindo que as respostas dos prudentes teriam força de lei e seriam obrigatórias para o juiz, quando elas tivessem sido dadas no mesmo sentido. Conferindo, assim, aos jurisconsultos que haviam obtido o ius respondendi a qualidade de verdadeiros funcionários imperiais, amesquinhava-se por isso mesmo todos os outros, e a jurisprudência devia necessariamente tomar a direção que lhe imprimissem os homens de lei do Imperador, que ele havia convocado para o seu Conselho, e, para melhor neutralizar a influência dos jurisconsultos independentes, ali se encontravam os chefes das duas grandes escolas dos sabinianos e dos proculeanos, os dois maiores jurisconsultos da época, SAlvio Juliano e JuVÊNCIO CELSO ${ }^{52}$.

É, também, sob ADRIANo que aparecem, pela primeira vez os rescripta que resolvem questões de direito, e que são preparados pelos jurisconsultos do Conselho do Imperador.

Quanto ao ius edicendi, a codificação do Edito por JULIANo, com sua aprovação por um senatusconsulto que lhe atribuiu força de lei, destinava-se não a reformar o direito pretoriano mas a estabilizá-lo ${ }^{53}$, no sentido de retirar dos magistrados a liberdade de redigir o Edito a seu modo, pois eles deveriam se submeter ao Edito Perpétuo do Imperador ${ }^{54}$.

Com a entrada em vigor do Edito Perpétuo, o Pretor não perdeu completamente o ius edicendi, mas como esclarece GLASSON ${ }^{55}$, foi-lhe retirado esse direito com relação a todas as partes do Edito Urbano que foram codificadas por JuLIANo; para o restante, aquele direito permaneceu como antigamente.

O Pretor conservou o ius adjuvandi, supplendi, corrigendi juris civilis gratia, e esse seu direito se aplicava, também, ao Edito Perpétuo tornado uma lei, como se aplicava a todas as outras leis. Todavia, o Pretor não podia mais por uma disposição nova abrogar uma regra do Edito Perpétuo, como ele podia fazer antes, em relação ao Edito de seu predecessor.

52. Glasson, Etude, cit. p. 269, 270.

53. Schulz, History, cit., p. 286.

54. Glasson, Étude cit., p. 270; Schulz, History cit., p. 127.

55. Glasson, Etude cit., p. 312, 313; ver também Charvet op., p. 116. 
"C'est par ce côté que la puissance des magistrats fut singulièrement affaiblie", disse GLASSON.

De igual modo quanto ao Conselho de Estado, composto de jurisconsultos oficiais e assalariados, observou ScHULZ ${ }^{56}$ que sua organização por ADRIANo foi a contrapartida da codificação do Edito, e do desuso do ius auctoritate principis respondendi. "The ancient right of the jurist to apply and develop the law was respected, but the bureaucratic tendencies of the times demanded centralization and officialization. The ancient aristocratic jurisprudence was gradually coming to an end".

Assim, a cláusula geral do Edito Urbano, consolidada no Edito Perpétuo, nos revela que o Pretor conservou a liberdade de conceder a r.i.i. em outros casos não previstos, mas sempre que as leis não proibissem, e, entre as leis, contava-se, agora, o Edito de Juliano, que o Pretor devia observar na redação de seu Edito ânuo.

4. A natureza da r.i.i, como ato pretoriano, tem merecido de autores modernos conceituação diferente, tendo em vista as expressões empregadas por PAULO e por ULPIANO em dois textos que estão, por assim dizer, no centro das discussões sobre a distinção entre imperium e iurisdictio ${ }^{57}$ :

PAULO: Ea, quae magis imperii sunt, quam iurisdictionis, magistratus municipalis facere non potest"' (Dig. 50.1.26)

ULPIANo: Jubere caveri praetoria stipulatione, et in possessionem mittere, imperii magis est, quam iurisdictionis (Dig. 2.1.4)

LUZZATTO e LAURIA ${ }^{58}$, entre outros, são de opinião que a referência a atos que são magis imperii quam iurisdictionis demonstra o conhecimento pelos jurisconsultos clássicos da conexão entre os dois conceitos e da existência de figuras limites, que participavam das características de ambos, tal como os demais remédios pretorianos que tinham a natureza de atos de imperium mixtum ${ }^{59}$.

56. Schulz, History cit., p. 118.

57. Raggi, La Restitutio cit,, p. 99; FABbrini, Per la Storia cit. p. 201 e segs., Sobre a questão dos "atti magis imperii quam iurisdictionis" ver CaRLo GiofFredi, Contributo allo studio del processo civile romano, Milão 1947, p. 26 e segs.

58. G. I. Luzzatto, Procedura Civile Romana, Parte II, Bolonha 1948, p. 194 ; M. LaURIA, "Iurisdictio" cit., p. 517.

59. V. Scialoja, Procedura Civile Romana, Roma 1936, p. 73. 
Para RAGGI ${ }^{60}$, a distinção não oferecia qualquer relevo prático, uma vez que ambas as categorias de atos competiam aos magistrados investidos de imperium, e o problema se colocava somente em relação à competência dos magistrados municipais, carecedores do imperium, a que se referem os textos de Paulo (Dig. 50.1.26 e $\S 10^{\circ}$ )

Ao contrário, com respeito ao processo formulário, o problema da distinção entre imperium e iurisdictio, segundo PUGLIESE ${ }^{61}$, cessa de permanecer puramente teórico e conceitual, para tornar-se prático, quando se pensa que os magistrados investidos de iurisdictio, mas privados de imperium, não podiam praticar qualquer dos atos que os juristas definiram magis imperii quam iurisdictionis, entre os quais a r.i.i.

Como quer que seja, no período republicano a natureza da r.i.i. era certamente a de um ato fundado sobre o poder de império do magistrado. $\mathrm{Na}$ verdade, como acentua FABBRINI ${ }^{62}$, é somente sobre seu imperium que o magistrado podia fundar-se para uma decisão tão extraordinária que reduzia a nada - magicamente por assim dizer - uma situação já válida e produtora de efeitos pelo ius civile, e com a qual evocava de repente uma situação jurídica anterior, para restabelecê-la.

Em sua configuração pretória a r.i.i. representa o instrumento conceitual típico da mentalidade da época, que desconhecia a idéia de anulabilidade, e que estava afeita apenas à concepção da nulidade, de tal modo rigorosa, que aquele remédio extraordinário, contra atos formalmente válidos, ficava circunscrito a poucos casos de particular gravidade e relevo social.

Somente assim é possível compreender-se como possa ter-se radicado na mentalidade romana uma atitude tão singular, como é a que inspira o instituto restitutório, pelo qual se admitia a possibilidade de fazer uma determinada situação realizar "un salto indietro nel tempo", e considerá-la nunca ter existido, para sustentar como existente tão só aquilo que, na realidade, era o status quo ante ${ }^{63}$.

60. RAGGI, La Restitutio cit., p. 98.

61. Giovanni Pugliese, Il processo civile romano - II, Il processo formulare, t. I, Milão 1963 , p. 119.

62. FabBrini, Per la storia, cit., p. 203.

63. RAGGI, La Restitutio cit., p. 267; FabBrinI, Per la Storia, p. 204. 
Por essa forma vinha a desaparecer uma situação jurídica, do mesmo modo como o Pretor, em virtude do seu imperium podia "criar" situações novas ${ }^{64}$.

$\mathrm{Na}$ experiência republicana, de acordo com a mentalidade dominante, o respeito quase religioso pelo ius civile - no qual se via o fundamento mesmo da organização social romana era acompanhado da mais larga confiança nas funções pretorianas, entendidas como prudente exercício de um poder amplamente discricionário, que, sem subverter diretamente os fundamentos civilísticos da ordem jurídica, era capaz de assegurar, com equilibrado recurso a valorações equitativas, uma tutela realística dos interesses pessoais e coletivos.

São assim estes os dois pressupostos com que se rege inicialmente o instituto restitutório, escreve RAGGI ${ }^{65}$ : a perfeita validade civilística do ato, por isso mesmo imodificável, e a avaliação perspicaz das razões de eqüidade que sugeriam um resultado diverso para a situação.

Mas, a reintegração do estado jurídico anterior, obtida mediante a atuação da potestade do Magistrado, na realidade se operava por ficção.

Como disse HENRI AUBERT "6, "la restitutio in integrum n'opère pas un rétablissement véritable, mais la simple fiction de ce rétablissement", que KUNTZE chamou de o avesso da realidade "das gegentheil der wirlichkeit".

Concedido o remédio extraordinário, as partes eram restituídas à situação anterior como se o fato não tivesse ocorrido, desaparecendo os seus efeitos prejudiciais que, então, cessavam de se produzir.

Observou SAVIGNY ${ }^{67}$, que essa reintegração, conforme a terminologia jurídica romana, não era designada como uma verdadeira e própria reintegração (ipso iure) mas somente como uma ficção daquela.

No campo do processo, "domaine dans lequel notre institution est le plus libéralment accordée", na expressão de CHARVET ${ }^{68}$, a conseqüência mais importante da concessão da

64. FABBRINI, op. cit. loc. cit.

65. RAGGI, La Restitutio cit., p. 268.

66. Henri AUBert, De l'in Integrum Restitutio, cit., p. 12 nota; VITA Levi, De Restitutione cit., p. 4 , nota 1.

67 Savigny, Sistema cit., v. 7, p. 119.

68. Charvet, Évolution cit. p. 120. 
r.i.i. pelo Pretor era precisamente de outorgar ao interessado uma ação, de direito honorário, conhecida como actio ficticia, cuja fórmula redigida pelo Pretor pôde ser reconstituída no que ela tem de essencial, segundo LENEL ${ }^{69}$, a partir dos comentários de GAIO IV, 38 a propósito da ação útil de rescisão da capitis deminutio, "id est in qua fingitur capite diminutus deminutave non esse."

Mediante a concessão da r.i.i. o Pretor restituia o interessado na posição em que se encontrava anteriormente, de ter de novo aquelas ações que ele havia perdido por motivos contra os quais era concedida a restituição, mas como as ações de direito civil não podiam renascer, pois era efeito da litiscontestatio nos iudicia legítima a consumação da ação, o Pretor concedia uma ação útil, com a fórmula fictícia, na qual se fingia que o ato ou o fato, que segundo o direito civil tinha produzido a perda da ação, não havia ocorrido ${ }^{70}$.

Por esse modo era possível restabelecer-se o direito da parte, que havia sido lesado por um ato contrário à eqüidade segundo o direito pretoriano.

5. Tema dos mais debatidos na doutrina, a propósito da r.i.i., é o da forma que revestia o auxilium extraordinarium concedido pelo Pretor, ou seja, o das características do ato pelo qual se manifestava o provimento pretoriano.

A esse respeito se contrapõem, ainda agora, duas teses. A primeira, proposta em 1831 por BURCHARDI ${ }^{71}$, com apoio na opinião de antigos romanistas do século XVII, sustenta que o processo da r.i.i., em todos os casos de sua aplicação, estaria sempre subdividido em duas fases bem distintas: a inicial, destinada a apurar o fundamento dos motivos apresentados pela parte que invocava o benefício do auxilium extraordinarium, e que se desenvolvia perante o Pretor, o qual conhecendo dos motivos alegados - causa cognita proferia um Decreto pronunciando a rescisão do ato impugnado; na fase subseqüente tinha lugar a instauração de um

69. LENEL, L' Édit cit. v. I, p. 135.

70. Scialoja, Procedura cit. p. 250. A propósito da actio utilis ex restitutiones consulte-se a monografia de Emilio Valino, Actiones Utiles, Pamplona 1974, na qual é examinada exaustivamente a função dessa ação como meio para realizar in iudicio a r.i.i. concedida pelo Pretor.

71. BURCHARDI, DieLehre Von der Wiedereinsetzung in den vorigen stand, Götting 1831, §§ 24, 25 e 26, citado por SAviGNY, Sistema v. 7, p. 286, nota 1. Um resumo bem elaborado dessa doutrina tradicional é apresentado por VITA LeVI, que a sustenta, op. cit. p. 68, 69. 
verdadeiro juízo, denominado iudicium rescissorium, no qual se faziam valer as conseqüências práticas da rescisão decretada pelo Pretor.

A tese de BuRchardi foi aceita em linhas gerais por SAVIGNY ${ }^{72}$, que a desenvolveu, entretanto, de maneira um pouco diferente e menos esquemática. Segundo o grande romanista, em alguns casos o auxilium podia ser obtido com um simples Decreto do Pretor, em seguida a uma cognitio, que desde logo exaure plenamente a questão, de modo a não restar mais nada por fazer.

Este caso ocorre sempre na restituição contra omissões ou erros no processo, uma vez que o Decreto repõe as partes restituídas na mesma posição anterior, como se a omissão ou o erro não tivesse acontecido.

Em questões mais complexas, porém, verificava-se a bipartição em dois processos separados, e a restituição podia ser considerada como um remédio condicionado, porquanto obtém para o lesado uma vantagem efetiva somente com a condição que ele vença o segundo processo.

As duas fases eram denominadas pela antiga doutrina iudicium rescindens e iudicium rescissorium, respectivamente, embora a primeira expressão seja imprópria e não apareça nas fontes ${ }^{73}$.

A justaposição iudicium rescindes - iudicium rescissorium, abandonada atualmente pelos romanistas, sobrevive no campo do moderno direito processual, para indicar as duas fases no procedimento de revogação das sentenças.

ENGELMANN ${ }^{74}$, ao tratar da questão, assinala que o procedimento seguido pelo Pretor podia variar. Para efetuar a restituição ele podia, após prévia causae cognitio, determinar por decreto a execução de um ato, ou ele próprio executar um ato, que tem, como seu imediato resultado, a restauração da situação anterior, ou ele podia ordenar um iudicium, não admissível em conformidade com o direito estrito.

Ele adotava o primeiro método quando, por exemplo, decretava que uma pessoa na posse de uma coisa alienada por

72. SavignY, Sistema v. 7, p. 286-294.

73. Savigny, Sistema v. 7., p. 288; Georges Vidal, La Restitutio, cit., p. 47; Cervenca, Per lo studio cit., p. 605, nota 15.

74. Arthur Engelmann; Der Römische Civilprozess, v. 2 da Geschichte des Civilprozesses, Breslau 1891, trad. inglesa de Robert Wyness Millar, in A History of Continental Civil Procedure, New York 1969, § 46, p. 310. 
um menor devia restituí-la ao menor (Dig. 4.4.13, § 1), ou corrigia uma fórmula que, em razão de erro, não se adapta ao caso sob discussão, ou foi elaborada defeituosamente.

o último método é o escolhido quando o Pretor concedia uma actio ou exceptio, o qual, em conseqüência do fato que constituía o motivo da restituição, podia não ser bem sucedido, conforme às regras ordinárias do direito. $\mathrm{O}$ novo iudicium é então chamado restitutorium ou rescissorium.

WENGER ${ }^{75}$ admite, também, a emissão do Decreto do Pretor para declarar se subsiste ou não uma válida razão de restituição, mediante prévia causae cognitio, quando ele examinava pessoalmente a causa, ou atribuía a um iudex essa indagação, o qual, no chamado iudicium rescindens, devia julgar, simplesmente com uma sentença de determinação, se subsiste ou não o motivo de restituição.

Após a emissão do Decreto, e respectivamente da sentença no iudicium rescindens, quando afirmasse que havia uma razão de restituição, dispunha o Pretor, segundo WENGER, de diversos meios para conseguir o restabelecimento do estado de direito anterior, um dos quais consistia na concessão da fórmula rescisória fundada na ficção de que o fato lesivo não tivesse ocorrido, por exemplo o usucapião de um bem em prejuízo de um ausente rei publicae causa ${ }^{76}$. Somente a sentença proferida neste iudicium rescissorium podia então ser executada.

Em amplo estudo sobre o tema, CARRELli ${ }^{77}$ retomou a tese de BURCHARDI e a levou às suas últimas conseqüências, sustentando a necessidade de um Decreto pretoriano de rescisão, distinto do sucessivo iudicium rescissorium, para todos os casos de aplicação da r.i.i., sem reconhecer a possibilidade de exceção à essa regra geral, como já havia sido admitido pela doutrina tradicional posterior a BURCHARDI ${ }^{78}$.

Com efeito, GLUCK ${ }^{79}$, examinando a doutrina tradicional sustentada por antigos autores, demonstrou que os modernos

75. WENGer, Istituzioni, cit., p. 243.

76. Sobre a redação dessa fórmula, que repousava na ficção de que o usucapião não tinha se consumado, bem como sobre o alcance da cognitio do Pretor nesse caso, ver as considerações de LENEL, v. I, p. 138-140.

77. OdOARDo CARRelli, Decretum e sententia nella restitutio in integrum, nos Annali della Facoltá di Giurisprudenza dell'Universitá di Bari, 1938, p. 129-221.

78. Cf. Cervenca, Per lo studio, cit., p. 606 e Studi Vari, cit., p. 25-26.

79. GLück, Commentario alle Pandette, cit. livro IV, p. 16-20, ver nas notas 41 e 43 os autores antigos e modernos citados por GLÜCK. 
romanistas rejeitavam a necessária bi-partição do processo, com a conseqüente emissão de um Decreto do Pretor, admitindo que, em muitos casos o Pretor concedia desde logo a actio rescissória remetendo as partes ao juízo, no qual se apurava a ocorrência do motivo invocado da r.i.i, que comprovado dava lugar à rescisão do ato lesivo por sentença do iudex.

A tese de CARRELli foi submetida por LAURIA ${ }^{80}$ a uma rigorosa análise, que o conduziu à conclusão de que o Decreto do Pretor, tal como resulta das fontes, teria sido emitido somente em alguns casos, especialmente em matéria administrativa ou penal, enquanto que, em regra o Pretor teria outorgado a r.i.i. sem um prévio Decreto, concedendo diretamente ao interessado a actio rescissoria. Somente nesses casos em que a r.i.i. não era pressuposto para ulteriores providências do magistrado ou atos da parte, é que o Decreto seria indispensável.

A divergência entre os romanistas quanto a essas duas teses é antiga, como refere GLUCK, sendo que, modernamente, a literatura vem orientando-se preferentemente para a tese de LAURIA, como demonstrou CERVENCA ${ }^{81}$, servindo de exemplo a autorizada opinião de ARANGIO-RUIZ ${ }^{82}$.

Ultimamente, CERVENCA ${ }^{83}$, tendo passado em revista as teses divergentes, à luz dos textos que examinou um por um, concluiu seu estudo sustentando que se deve rejeitar a tese que nega a necessidade do Decreto em todos os casos de aplicação da r.i.i., como é a de KARLOWA ${ }^{84}$.

Do quanto é possível deduzir-se do enxuto testemunho das fontes sobre a matéria - mesmo na ausência de provas seguras a respeito - entende CERVENCA que se possa sustentar que o Pretor recorria ao Decreto quando a r.i.i. não se destinava a encontrar atuação em um posterior iudicium, porém

80. LAURIA, Iurisdictio, cit., p. 514 e segs.

81. Cervenca, Per lo Studio, cit. p. 606 e Studi Vari, cit., p. 26 e a ampla bibliografia referida.

82. Arangio-Ruiz, Istituzioni di Diritto Romano, 1 . $^{\text {a }}$ ed. Napoles 1952, p. 143, nota 1. No mesmo sentido RagGi La Restitutio, cit., p. 176; Marro AmeLotTI, La prescrizione delle azioni in Diritto Romano, Milão 1958. p. 39; IMPallomeni, Studi sui mezzi di revoca degli atti fraudolenti nel Diritto Romano Classico, Padua 1958, p. 45.

83. Cervenca, Studi Vari, cit., p. 59.

84. KARLOWA, Römische Rechtsgeschichte, Leipzig 1901, v. II, p. 1090 citado por Cervenca, Stū di Vari, cit., p. 26, nota 62. 
em um ato extrajudicial. São relativamente em menor número as provas da existência do Decreto, quando a r.i.i. era destinada a ser atuada por meio de um iudicium rescissorium, enquanto que, ao contrário, outros textos fazem certo que, nesse caso, a r.i.i. podia vir a ser outorgada diretamente com a concessão do próprio iudicium rescissorium.

Nos casos em que o Pretor, causa cognita, concedia a restituição mediante um Decreto, a questão se encerrava independentemente de qualquer posterior julgamento judicial, devendo a parte, contra a qual foi decretada a restituição, submeter-se e cumprir a ordem pretoriana.

Era o que acontecia, por ex., no caso de venda de um fundo em que o vendedor menor tivesse sido enganado pelo comprador... si in vendendo fundo circunscriptus restituetur, iubeat Praetor emptorem fundum cum fructibus reddere et pretium recipere. (Dig. 4.4.24 § 4).

Quando, em vez de dirimir pessoalmente a questão o Pretor, reconhecendo o fundamento da causa, concedida ao interessado diretamente a actio rescissoria, instaurava-se, então, em seguida, o correspondente iudicium rescisorium, com base na fórmula elaborada pelo Pretor, que por dizer respeito a uma ação honorária, e não do direito civil, era uma fórmula com ficção, que impunha ao iudex o dever de pronunciar a sentença como se o ato impugnado não tivesse ocorrido ${ }^{85}$.

6. Examinando a evolução do processo do Ordo iudiciorum e da extraordinaria cognitio durante o Império Romano, PERNICE ${ }^{86}$ observou que, durante a República a cognitio era usada pelo Cônsul, pelo Censor e, em certas causas, também pelo Pretor, sendo certo que as cognitiones do Pretor não tinham larga aplicação.

Entre os casos em que a cognitio praetoria tinha naturalmente lugar, PERNICE põe em destaque a restituição, assinalando que o Pretor, anunciando em seu Edito os motivos de restituição, se vinculava somente com respeito a estes, mas no resto se reservava liberdade de ação. E por isso dependia da sua vontade, ou mais freqüentemente da natureza do caso,

85. Cervenca, Studi Vari, cit., p. 38 e p. 26, nota 59.

86. A. Pernice, Volksrechtliches und Amtsrechtliches Verfahren in der römischen Kaiserzeit, in Festgabe Beseler, Berlim 1885, p. 51-52, trad. de Gaudenzi, L'Ordo Judiciorum e L'Extraordinaria Cognitio durante L'Impero Romano, no Archivio Giuridico, 1886, v. 36, p. 116-117. 
o valer-se da sua autoridade para a restituição ou de conceder uma actio rescissoria.

A causae cognitio representava, então, a reserva para o Magistrado do direito de acolher ou de recusar o pedido. Comumente esta reserva é exprimida pelas palavras causa cognita iudicium dabo, mas encontram-se nas fontes outras alocuções para exprimir a mesma idéia como, no caso específico da r.i.i., si quae mihi alia justa causa videbitur (Dig. 4.6.1 \& $\left.1 .^{\circ}\right)$, si de his rebus alia actio non erit et justa causa esse videbitur (Dig. 4.3.1 § $1 .^{\circ}$ ).

Ao que parece, segundo a tese sustentada pela generalidade dos romanistas, salvo em raríssimas hipóteses como no caso de "capite minutis" consoante a reconstituição de LENEL ${ }^{87}$, em que o Pretor concedia diretamente o iudicium rescissorium sem uma prévia causae cognitio (Dig. 4.5.2 $\left.\S 1 .^{\circ}\right)$, que nesse caso o Pretor devia conceder incondicionalmente, como disse SAVIGNY ${ }^{88}$, nos demais, causae cognitio constituía o pressuposto indispensável para todos os casos de aplicação da r.i.i.

Que a causae cognitio constituía o pressuposto de toda concessão da r.i.i. pelo Pretor resulta de uma explícita afirmação de Modestino: Omnes in integrum restituitiones causa cognita a Praetore promittuntur; scilicet ut iustitiam earum causarum examinaret, an verae sint, quarum nomine singulis subvenit. (Dig. 4.1.3)

Entendem alguns autores ${ }^{89}$ que esse texto teria sido interpolado pelos compiladores do Digesto, e que não corresponde ao original de ModEstino, tal como devia constar no seu livro viII Pandectarum.

Esse ponto de vista sustentado inicialmente por RICCoBONO ${ }^{90}$, em 1922, foi posteriormente desenvolvido por MARTINI ${ }^{91}$, com copiosa argumentação.

Antes do estudo de MARTini, Lemosse já havia assinalado que a doutrina mais rescente parecia negligenciar essa

87. Cf. LENEL, op. cit., v. I, p. 133.

88. Savigny, op. cit., v. 7, p. 262.

89. Maxime Lemosse, Cognitio, étude sur le role du juge dans l'instruction du procés civil antique, Paris 1944, p. 202, nota 3.

90. Cf. Lemosse, Cognitio, cit. p. 202.

91. Remo Martini, Il problema della causae cognitio pretoria, Milão 1960 , especialmente p. 74 e segs. 
conjectura da interpolação do texto, e admitir implicitamente a opinião contrária. "Que le style puisse sembler suspect, il n'importe; le fond est certainement authentique" ${ }^{92}$.

De igual modo CERVENCA ${ }^{93}$, contestando a tese de MARTINI, cujas afirmações refutou uma a uma, defendeu a genuidade do texto, afirmando, ainda, que a regra enunciada por aquele jurista é inequívoca e, nos termos em que está expressa, mostra-se, sem dúvida alguma, de alcance geral.

A causae cognitio, referida por Modestino, não deve, então, ser entendida no restrito significado de apreciação discricionária do Pretor, porém no sentido mais amplo de verificação da correspondência ao caso concreto da abstrata hipótese-tipo prevista no Edito.

Como observou LÉVY-BRUHL ${ }^{94}$, a causae cognitio que tem lugar na atividade do Pretor nas estipulações pretorianas, nas missiones in possessionem, nas restitutiones, realiza em larga medida, em proveito do Pretor, a confusão do ius e do iudicium. Em matéria de ações, a cognitio só acompanha as que são criadas pelo Pretor, não se aplicando jamais às ações de direito civil. $\hat{E}$ que estas o Pretor as concedia tal como haviam sido concebidas pelo legislador, sem qualquer condição ou modificação. Quanto ao fundamento mesmo da causae cognitio, LÉVY-BRUHL ${ }^{95}$ formulou a hipótese de se tratar de uma espécie de ganga protetora com a qual envolve as instituições que ele vai criando, ou sobre as quais, por uma razão qualquer, ele deseja manter a direção principal.

No fundo, é uma reserva de controle sobre as inovações que vai introduzindo. No dizer de LEMOSSE ${ }^{36}$, "parfois, le préteur crée véritablement un moyen nouveau, anormal; il veut controler ses innovations". Uma prova da prudência do Magistrado, que se reserva o controle sobre as novas instituições por ele criadas, destinado a desaparecer à medida que essas instituições se consolidam.

92. Lemosse, Cognitio, cit., p. 203.

93. Cervenca, verbete Restitutio in Integrum no Novis. Dig. Ital., XV, p. 741, nota 4, e Studi Vari, p. 8 a 20.

94. HENRI LEVY-BRUHL, La causae cognitio sous la procédure formulaire, em Revue d'histoire du droit, Bruxelles-La Haye, 1924, t. V, p. 389-392.

95. HenRI Levy-Bruhl, La denegatio actiones sous la procédure formulaire, Lille 1924, p. 59.

96. Lemosse, Cognitio, cit., p. 187. 
Desse modo, vê-se que a causae cognitio está intimamente ligada às atribuições legislativas do Pretor, das quais constitui como que uma espécie de corretivo. ${ }^{97}$

A causae cognitio, que o Pretor se reservava, levou alguns autores, como BURCHARDI, a qualificar a restituição como ato de graça, mas essa opinião foi vivamente combatida por outros autores, entre os quais PUCHTA, que a situa na esfera dos atos jurídicos, demonstrando HENRI AUBERT ${ }^{98}$ que a razão estava com estes últimos, pois, a denominação de ato de graça aplicada à r.i.i. pode, com efeito, levar a conseqüências inexatas.

No começo, sem dúvida, o Pretor se reservava o direito de pronunciar a restituição quando a julgasse conveniente; mas, precisando em seu $E$ dito as causas para as quais a concederia, ele se privou do poder de a recusar, quando as condições prescritas tivessem sido satisfeitas. A cognitio praetoris se limitava então a pesquisar simplesmente se essas condições existiam realmente ${ }^{99}$.

Mas, se se admite que esses eram efetivamente os poderes do Pretor na época clássica, a questão de saber se a r.i.i. é, ou não, um ato de graça, se reduz a uma pura questão de palavras, consoante a observação de SAVIGNY ${ }^{100}$ a propósito dessa disputa.

A importância que a causae cognitio praetoris assume em correlação com a r.i.i. foi posta em relevo por CERVENCA, com a indicação de textos nos quais a postulatio dos interessados na r.i.i., em vez de ser dirigida, como de regra, para a obtenção da própria restituição, tem por objeto diretamente a cognitio pretoria, que assim se revela como um pressuposto da r.i.i.: “. . uta puta postulata est cognitio de in integrum restitutione, cum minor circumscriptus in venditione diceretur..." (Dig. 3.3.39.6)

Pomponius adicit ex his causis, ex quibus in re peculiari filii familias restituuntur, posse et patrem quasi heredem nomine filii post obitum eius impetrare cognitionem. (Dig. 4.4.3.9).

97. LEVY-BRUHL, La denegatio, cit., p. 60.

98. H. AUBert, De l'in Integrum Restitutio, cit., p. 11.

99. Cf. Giovanni Pugliese, verbete Cognitio, no Novis. Dig. Ital. III, p. 433, n. $^{\circ} 3$.

100. SAVIGNY, op. cit., v. 7, p. 141. 
Minor viginti quinque annis fundum vendidit Titio, cum Titius Seio: minor se in ea venditione circunscriptum dicit et impetrat cognitionem nom tantum adversus Titium, sed etiam adversus Seium... nam si ei fundus praetoria cognitione ablatus fuerit... (Dig. 21.2.39).

O confronto entre esses casos, em que o objeto da postulatio da r.i.i. é identificado na cognitio pretoria, e a massa dos outros casos em que a postulatio tem por objeto a própria restituição, levou CERVENCA ${ }^{101}$ a afirmar que, toda vez que nas fontes se fala em postulare in integrum restitutionem, isso equivalha a dizer postulare cognitionem (de in intregrum restitutione). "Il che starebbe dunque a confirmare che fondamento della restitutio in integrum è per l'appunto, la cognitio del pretore".

7. A circunstância de no Edito estarem previstos conjuntamente, para os casos de dolo e de medo, o extraordinarium auxilium da r.i.i. e as correspondentes ações quod metus causa e de dolo malo, suscitou séria dúvida quanto à importante questão de natureza histórica a propósito da precedência desses meios jurídicos da atuação do Pretor.

Qual deles foi por primeiro concedido pelo Magistrado? A r.i.i. nesses casos, antecedeu ou sucedeu à correspondente actio?

Duas soluções opostas foram apresentadas. Segundo BURCHARDI ${ }^{102}$, no decurso do tempo a r.i.i. teria sido preferida às várias ações ordinárias e vinha sendo freqüentemente mais aplicada que antes. A preferência era devida ao processo mais rápido e breve, e, também, à vantagem prática para o autor de obter de novo a coisa perdida, enquanto que, na ação arbitrária o réu podia escolher entre restituir a coisa ou ser condenado no ressarcimento. A r.i.i. seria, assim, um remédio pretoriano mais perfeito que a actio, tendo sucedido àquela.

GEORGES VIDAL ${ }^{103}$, em sua tese de doutorado, esposa o mesmo entendimento, de que a r.i.i. teria sido introduzida por último, como meio mais enérgico que a actio, sem fazer qual-

101. Cervenca, Studi Vari, cit., p. 21.

102. BURChARDI, Die Lehre von der Wiedereinsetzung, cit., §§ 19, 20, p. 361363,382 , citado por SAVIGNY, op. cit., v. 7, p. 140, nota g. A opinião de BURCHARDI é amplamente exposta e analisada por MASSimo BRUTTI, La problematica del dolo, cit., v. II, p. 383 , nota 96 .

103. GEORGES VIDAL, De la Restitutio, cit., p. 6. 
quer referência à opinião de BURCHARDI, que não é citado nesse trabalho. Para VIDAL, "Le préteur n'a certainement pas commencé par se mettre en guerre ouverte avec le droit civil et ses prémiers essais ont dû être plus timides. C'est par le moyen des exceptions que les prémiers coups ont, vraisemblablement, été portés; les actions prétoriennes sont venues ensuite en combler l'insuffisance. Ce ne fut qu'en dernier lieu, lorsque le respect du vieux droit des XII tables allait s'affaiblissant tandis qu'au contraire le pouvoir et l'audace du préteur grandissaient, que ce magistrat établit le moyen, à la fois plus énergique et plus prompt, de la restitutio in integrum".

Partindo do pressuposto de que a r.i.i. no período republicano, por depender sua concessão do arbítrio do Pretor, em razão do seu poder de imperium, constituía um remédio primitivo, juridicamente imperfeito, SAVIGNY ${ }^{104}$ sustentou a tese oposta, da anterioridade da r.i.i..

De maior importância foi o fato de que os Pretores em alguns casos transformaram a restituição, que anteriormente concediam, em ações e exceções ordinárias, mudando assim a regra, até então incompleta, em uma norma estável e completa, escreve o grande romanista, que acrescenta dever-se reconhecer nisso o desenvolvimento natural da formação orgânica do direito, pois que, pouco a pouco, a regra jurídica, no princípio informe e que devia completar-se com uma livre autoridade pessoal, vem transformada em uma regra certa e completa, e, assim, o auxilium extraordinarium se resolve em um commune auxilium.

Observou Charvet 105, que essa conjectura de SAvignY, sedutora à primeira vista, foi muito atacada na segunda metade do século XIX. Esforçaram-se os autores ${ }^{106}$ por mostrar, notadamente em matéria de metus e de dolo malo, que os remédios chamados normais, ação e exceção, tinham precedido a r.i.i., e, nessa reação contra a hipótese de SAVIGNY, voltaram à tese de BURCHARDI.

Na conclusão de seu trabalho CHARVERT ${ }^{107}$, sem endossar o ponto de partida de SAVIGNY, de uma generalização que leve

104. Savigny, op. cit., v. 7, p. 136-139.

105. Charvet, Évolution, cit., p. 5.

106. A exposição da opinião desses autores com as indicações bibliográficas encontra-se no estudo de DUQuesne, Cicéron, Pro Flacco c. 30-32 et l'in integrum restitutio, cit., p. 302 e segs. - Cf. CHARVET, Évolution, cit., p. 5, nota 3.

107. Charvet, op. cit. p. 124. 
a estabelecer o princípio da anterioridade da r.i.i. aos meios de processo concorrentes, inclina-se a ver, com o grande romanista, na r.i.i. uma instituição de origem muito antiga que tende a se absorver nas vias de recursos ordinários. Com essa correção, a opinião de SAVIGNY parece-lhe ser a que dá a mais justa idéia da evolução da r.i.i. no direito privado romano.

A questão é colocada e analisada por SAGENTI ${ }^{108}$ " sob um prisma inteiramente diverso.

Baseando-se no exame das fontes republicanas que confirmam a remota antigüidade das aplicações da restitutio, entende ele que essas fontes não oferecem qualquer pretexto para fundamentar aquela hipótese a propósito de sua formação histórica, e, ao contrário, conduzem a exclui-la da maneira mais certa.

Isso porque, no seu entender, a restitutio não nasceu por uma iniciativa do Pretor, determinada pela intenção de tutelar posições individuais ameaçadas ou comprometidas por atos praticados sob o efeito da violência ou do dolo, mas sobre um plano de exigências e de relações de caráter publicístico, em face de problemas políticos determinados por fatos bélicos, numa complexa situação criada pela expansão e pela ação política geral de Roma, e nasceu por uma germinação espontânea e ocasional, pelo jogo das relações político-constitucionais entre os vários órgãos do Estado romano e de suas ações com respeito aos territórios e às populações subjugadas e controladas.

A incerteza quanto à precedência, que motiva a divergência entre os autores, decorre da ausência de dados seguros a respeito da primeira aplicação das r.i.i. ob metum e $o b$ dolum.

Como observa CERvenca ${ }^{109}$, se são conhecidas as datas aproximadas da introdução da actio quod metus causa e da actio doli, não se pode dizer o mesmo a propósito das r.i.i. $o b$ metum e $o b$ dolum.

A actio quod metus causa pode ser identificada com a fórmula octaviana, introduzida pelo Pretor OTAvio, no ano 80 aC. aproximadamente; quanto à actio doli parece que a

108. SARgenti, Studi sulla Restitutio, cit., p. 293 e segs.

109. Cervenca, Per lo studio, cit. p. 603, nota 5 e verbete Rest. in Integrum no Novis. Dig. Ital., p. 741 , nota 1. 
relativa fórmula teria sido proposta pela primeira vez pelo Pretor Aquilio GALLO em 66 aC.

Da r.i.i. ob metum a primeira notícia de sua aplicação é fornecida por CÍCERo (In Verr. 2.2.26, 63) para o ano 70 $\mathrm{aC}$, enquanto que a primeira notícia da r.i.i., ob dolum, transmitida também por Cícero (Pro Flacco 30-32) remonta ao ano 64 aC.

Todavia, como ressaltou DUQUESNE ${ }^{110}$, se as notícias fornecidas por CÍCERo referem-se a aplicações da r.i.i. em datas posteriores à introdução das respectivas actiones, nada prova que essas tenham sido as primeiras aplicações do instituto, além do mais, porque, da linguagem de CícERo não transparece que as restitutiones concedidas naqueles dois casos fossem consideradas como provimentos novos e excepcionais.

A dúvida não pode ser resolvida, então, com a simples invocação dessas datas conhecidas.

No mais recente trabalho sobre a história da r.i.i., FABBRINI 111, embora admitindo que do confronto dessas datas se deve concluir pela anterioridade da r.i.i. em relação à respectiva actio, porque não é possível pensar que em tão curto período de tempo (10 e 2 anos respectivamente), tivessem surgido novas exigências tão urgentes de postular a aplicação do remédio extraordinário da r.i.i. como se as actiones, então conhecidas, tivessem se revelado de todo inadequadas e insuficientes logo no dia seguinte de sua criação — é de opinião que o critério mais seguro para resolver a questão é o de indagar sobre a natureza dos institutos que são postos em confronto.

A r.i.i., dado o seu caráter de remédio pretoriano exorbitante da normal iurisdictio, era criada para vir ao encontro de particulares exigências, lá onde não subsistissem ou fossem inadequados os meios normais à disposição do Magistrado para dar remédio às iniqüidades originadas pelo sistema do ius civile. Tratava-se de um meio extraordinário, para situações extraordinárias, a que se recorria enquanto fosse o único meio invocável em uma dada situação, isto é, quando a situação que se entendia de tutelar não era reconhecida no âmbito do direito civil.

110. Duquesne, Cicéron Pro Flacco, cit., p. 322; Charvet, op. cit., p. 41-42; CERVENCA, op. cit., loc. cit.

111. Fabbrini, Per la Storia, cit., p. 211. 
Ao contrário, a existência de uma actio pressupõe que dadas relações tenham-se normalizado dentro de uma esfera de juridicidade. Ela se coloca entre os meios ordinários e pressupõe no seu titular uma determinada expectativa, garantida pelo Pretor com sua iurisdictio.

Entre uma e outra situação, aquela tutelada pela restitutio e a tutelada pela actio, há uma notável diferença: a segunda pressupõe uma evolução com respeito à primeira, evolução que se concretiza em uma normalização, em uma jurisdicização de determinadas relações. Deduz-se então uma prioridade histórica da restitutio em relação à actio respectiva.

Com efeito, é muito difícil pensar que se tenha recorrido ao instrumento da restitutio para tutelar uma situação que já encontrava válida tutela entre os esquemas da iurisdictio ordinária.

Pelas mesmas razões, é de todo provável que a restitutio in integrum tenha sido anterior, também, à relativa exceptio, a qual precede cronologicamente, e, mesmo, de um ponto de vista lógico, a actio respectiva.

$\mathrm{Na}$ realidade a exceptio, também, pressupõe o reconhecimento de uma expectativa tutelada pelo Pretor através de sua iurisdictio.

Ao cabo dessa brilhante e convincente argumentação, FABBRINI formulou a seguinte hipótese sobre o progressivo desenvolvimento: de uma situação originária em que contra o negócio viciado não havia qualquer possibilidade de remédio, para uma situação na qual o Magistrado, tendo em conta as exigências da aequitas, excogitou o remédito da restitutio, baseado sobre um poder de caráter extraordinário que encontra seu fundamento no imperium; para passar depois a uma tutela ordinária nos limites da normal iurisdictio, primeiro concedendo ao interessado uma defesa passiva (exceptio), e finalmente a verdadeira e própria defesa do ponto de vista ativo (actio) ${ }^{112}$.

A linha evolutiva traçada pelo moderno romanista italiano aproxima-se da hipótese de SAVIGNY e, na falta de dados fáticos precisos, é a que se reveste da maior verossimilhança.

Aliás, no Império, depois da codificação das normas editais por JULIANo, foi estabelecida a regra de que o Magistrado

112. FabBrini, op. cit., p. 212. 
ao conhecer da causa, examinará também se compete outra ação além da restituição.

Porque, se pelo auxílio comum e mero direito estiver amparado, não deve o Magistrado outorgar-lhe o auxílio extraordinário. Foi o que escreveu UlPIANo em seus comentários ao Edito (livro XI), que os compiladores do Digesto transcreveram (Dig. 4.4.16)

8. No período clássico as ações pretorianas, de modo geral (GAIo IV-110, Dig. 44.7.35), eram concedidas e só podiam ser exercidas no prazo de um ano útil.

A regra abrangia, também, a maioria das medidas especiais de tutela de direitos, que o Pretor concedia durante a pretura.

É importante ressaltar, contudo, que o annus utiles não se confundia com o annus imperii ${ }^{113}$.

Salvo no caso excepcional de capitis minutis, cuja ação era perpétua (Dig. 4.5.2 §5), nos demais, previstos no Edito, o prazo para pleitear a concessão da r.i.i. era de um ano - o tempo útil a que se referem os textos, Dig. 4.4.19$4.4 .39-4.6 .1$. $\S 1-4.6 .28 \S \S 3$ e 4 . SOS ${ }^{114}$.

A esse propósito é pacífico o entendimento dos estudio-

No Império, Constantino, com uma longa e prolixa constituição, dos anos 315 ou $319^{115}$, introduziu uma profunda

113. AmelotTI, La prescrizione, cit., p. 100; RAGGI, La Restitutio, cit., p. 235 , nota 24.

114. Vita Levi, De Restitutione, cit., p. 113; G. Vidal, De la Restitutio, cit. 48; H. Auber, De l'in Int. Rest., cit., p. 62; Charvet, Evolution, cit., p. 3; RAGGI. La Restitutio, cit. p. 235, nota 23.

115. C. Th. 2, 16, 2 (Imp. Constantinus A. ad Bassum): Placuit post conpletum vicesimum et quintum annum ex eo, quo vicesimi et sexti anni dies inluxerit, ad interponendam contestationem in urbe Roma usque ad anni tricesimi extremum diem spatia prorogari, et intra centesimum urbis Romae miliarum, si tamen $a b$ his iudicibus, qui Romae sunt, fuerit iudicandum: per omnem vero Italiam usque ad finem anni vicesimi et noni: in ceteris omnibus provinciis usque ad conpletum annum vicesimum et octavum. Quo transacto tempore manifeste omnes sciant legum sibi deinceps praesidia denegari, quandoquidem contestationis necessitate depulsa finiendas integri restitutionum decidendasque causas certo genere clauserimus. Eandem autem custodiri temporum convenit rationem, si forte quis beneficio nostro aetatis veniam fuerit consecutus, ex eo die, quo indulgentia nostra in iudicio conpetenti fuerit intimata eique administratio rei propriae reserata, ut ad persequendas in integrum restitutiones finiendasque causas iuge tempus habeat praestitutum. Si quando sane in minoris iura successerit minor, minime prohibetur, cum quintum et vicesimum aetatis suae annum 
inovação com respeito ao prazo da r.i.i. dos menores de 25 anos.

O critério esposado na constituição para o estabelecimento de prazos diferentes era concernente ao domicílio do menor ${ }^{116}$.

O prazo passou a ser, então, de cinco anos quando a r.i.i. fosse demandada em Roma, ou no espaço de cem milhas da cidade; de quatro anos, se fosse no resto da Itália, e de três anos se em qualquer outra província do Império.

Constantino, no instituir os novos prazos, teve em vista, exclusivamente, os menores de idade, não cuidando a constituição de qualquer outro caso de r.i.i., o que levou alguns autores ${ }^{117}$ a sustentar que, no início do século IV d.C. a esfera de aplicação da r.i.i.i estaria restringida ao único caso da minoridade.

A opinião tradicional, exposta por SCHULZ ${ }^{118}$, todavia, é no sentido de que até JUSTINIANo permaneceu em vigor o prazo do ano útil para os demais casos de r.i.i., uma vez que a reforma de Constantino só objetivava a restitutio minoris.

No ano 531, JUsTINIANo, mediante uma constituição dirigida a JoÃo, Prefeito do Pretório modificou completamente

transierit, integri restitutiones beneficio uti tempore inlibato. Quod si maioris fuerit minor iura nanctus, quantum ad eas pertinet actiones, quas ex persona maioris fuerit consecutus, tantum temporis ad exponendas integri restitutiones decidendasque causas accipere debebit, quantum defuncto, cuius heres aut bonorum possessor docebitur extitisse, relicum fuerat. Cum vero maior successionem fuerit adeptus minoris, siquidem civili iure ab intestato vel ex testamento successerit, mox cum creta fuerit vel adita hereditas, si vero honorario iure, ex quo bonorum possessio fuerit accepta, examinando integri restitutionis negotio solida sine ulla deminutione tempora subputentur, quae non pro locis, regionibus atque provinciis, in quibus morantur qui heredes aut bonorum possessores sunt, observari iubemus, sed in quibus defuncti domicilia conlocaverant.

Sobre o problema das datas, cf. a edição MOMMSEN e KRüGer do Codex Theodosianus, ad C. Th. 2, 16, 2 e a edição Krüger do Codex Justinianus, ad C. 2, 52, 5; AmelotTi, La prescrizione, cit., p. 101, nota 253.

116. H. Auber, De l'in Int. Rest., cit. p. 63.

117. Levy, Zur nachllassischen in integrum restitutio, in Zeitschrift der Savigny - Stiftung, 1951, v. 86, p. 360 - 434, citado por CervencA, Studi Vari, p. 131, que aceita a opinião de LEVY e apresenta outros argumentos em seu reforço, p. 147 a 153. No mesmo sentido Амедотt, La prescrizione, cit. p. 102.

118. FRITZ SchuLZ, Interpolationem in den Justianischen Reform gesetzen des Codex Justinianus vom Jahre 534, nos Studi Bonfante, cit. v. Ip. 346 , citado por AMelotTI, La prescrizione, cit., p. 102. 
a situação, até então reinante, com a finalidade de uniformizar os prazos da r.i.i. tanto para os menores quanto para os maiores.

Disse o Imperador que, desterrando a supérflua diferença do ano útil da restituição, mandava que na antiga Roma, como nesta augusta cidade de Constantinopla, na Itália como nas demais províncias, se conte unicamente um quadriênio contínuo a partir do dia em que começava a correr o ano útil, e que esse tempo seja comum a todos os lugares; pois pareceu-lhe bastante absurdo que por diferença de lugares se introduzisse alguma diversidade. Mandando que se aplique por igual não somente às situações dos menores para quem o ano útil começa a correr a partir do primeiro dia do vigésimo sexto ano, senão, também, as dos maiores, a fim de que nestas se observe, também, em vez do ano útil a mencionada prolongação do tempo, para interpor a contestação e terminar o litígio ${ }^{119}$.

Sem embargo da dúvida quanto à originalidade do texto recolhido pelos compiladores do Codex repetitae praelectionis, levantada por ScHULZ, os motivos determinantes da modificação ordenada por JUsTiNiANo estão claramente expostos na constituição, dispensando qualquer comentário.

Com a reforma introduzida por JUsTiniano o prazo da r.i.i. passou a ser de quatro anos contínuos para as duas hipóteses, de restituição dos menores e dos maiores, únicas que sobreviveram após a absorção dos casos de r.i.i. pelo sistema de ações do regime imperial da extraordinária cog. nitio.

119. Codicis Repetitae Praelectionis. C. 2. 52. 7:

C. 2, 52 (53), 7 (Imp. Iustinianus A. Iohanni pp. - a. 531) : Supervacuam differentiam utilis anni in integrum restitutionis a nostra re publica separantes sancimus et in antiqua Roma et in hac alma urbe et in Italia et in aliis provinciis quadriennium continuum tantummodo numerari ex die, ex quo annus utilis currebat, et id tempus totius loci esse commune: ex differentia enim locorum aliquod induci discrimen satis nobis absurdum esse visum est. - 1. Quod non solum in minorum restitutionibus, quibus utilis annus incipit currere, ex quo vicesimi sexti anni dies illuxerit, sed etiam in maiorum hoc idem adhiberi sancimus, ut et hic pro utili anno memorata continuatio temporis observetur ad interponendam contestationem finiendamque litem. - 2. Et quemadmodum omnis minor aetas excipitur in minorum restitutionibus, ita et in maiorum tempus, in quo rei publicae caüsa afuerint vel aliis legitimis causis, quae veteribus legibus enumeratae sunt, fuerint occupati, omne praecipiatur, et sit non absimilis in hac parte minorum et maiorum restitutio. $D . k$. Sept. Constantinopoli post consulatum Lampadii et Orestae vv. cc. 
9. Nos séculos II e III d.C., no período do Principado, sob a influência da nova organização judiciária, estabelecida segundo um esquema hierárquico tendo no vértice o Imperador como suprema autoridade, o auxilium extraordinarium da r.i.i. passa por sensíveis modificações, que vão lentamente descaracterizando o antigo remédio pretoriano, à medida que o imperium do Pretor vai sendo absorvido pela autoridade do Imperador e, depois, pela do magistrado que por nomeação do Imperador exerce a iurisdictio em Roma, o Praefectus Urbi.

Em decorrência da burocratização da magistratura judiciária imperial, e, especialmente, da introdução do novo sistema processual da cognitio extra-ordinem, surge nesse período histórico o recurso da apelação ${ }^{120}$, como o meio, posto à disposição do vencido por uma decisão proferida pelo magistrado imperial encarregado de organizar o processo e julgar a lide, de submeter a causa ao superior julgamento do Imperador, com a finalidade de reparar a eventual injustiça da sentença.

Durante a República, a decisão do Pretor, concedendo ou denegando a r.i.i. segundo sua livre discricionariedade, era insusceptível de modificação, porque se fundava no imperium do magistrado.

No Principado ao contrário, ao lado do Pretor encontra-se o Praefectus Urbi, com atividade jurisdicional delegada pelo Imperador, na qual se compreendia o poder de rever a decisão do Pretor e cujo julgamento, por sua vez, podia ser reexaminado pelo Imperador mediante o recurso da appellatio. Tal é o sistema vigente na época dos Severos, segundo a informação transmitida pelo jurista PAULo no Libri Decretorum, de que os compiladores do Digesto transcreveram o longo fragmento da lei $38-D i g$. 4.4.38.

No que interessa ao tema, verifica-se do fragmento ${ }^{121}$ que uma pupilla tinha impetrado a r.i.i. ao Pretor e, tendo sido repelido o pedido, renovou-o perante o Praefectus Urbi, que também não o acolheu, recorrendo, então, ao Imperador, que resolveu em favor da concessão da r.i.i. contrariamente ao

120. Cf. Riccardo ORESTANo, L'Apello civile in diritto romano, $2 .^{\text {a }}$ ed. Turim, 1953, p. 186, e LUIGI RAGGI, Studi sulle impugnazioni civile nel processo romano, Milão 1961, p. 6.

121. Dig. 4.4.38: "pūpilla in integrum restitui desiderabat; victa tam apud Praetorem, quam apud Praefectum Urbi provocaverat. Putabam, bene iudicatum, quod pater eius, non ipsa contraxerat, Imperator autem motus est... pronuntiavit in integrum restituendam." 
parecer expresso de PAULo que reputara bem julgada a decisão de não conceder o remédio.

Como foi observado ${ }^{122}$ a propósito da subordinação hierárquica do Pretor ao Praefectus Urbi e, por último ao Imperador, que esse fragmento revela, tal subordinação, particularmente com respeito à r.i.i. - instituto do ius honorarium - constitui uma prova da decadência da autoridade pretória na última fase do Principado. Aliás, UlPIANo, outro sumo jurisconsulto da idade dos Severos, em seus Comentários ao Edito refere quais eram as autoridades que tinham o poder de conceder a r.i.i. indicando o Praefectus Urbi $e$ "os outros magistrados por sua jurisdição", sem nomear o Pretor, que estaria incluído na ampla e genérica expressão "alii magistratus" — Dig. $4.4 .16 \S 5{ }^{123}$.

Além do Praefectus Urbi em Roma, numerosos textos informam que, nas províncias, a r.i.i. era concedida pelos Praeses, segundo o sistema da cognitio extra-ordinem ${ }^{124}$.

Pela posição singular que assumira no ápice da hierarquia, o Imperador era, porém, quem dizia a última palavra sobre a r.i.i. mediante o conhecimento da appellatio, mas, não só pela resolução dos casos levados a seu julgamento pela via recursal, como, também, pela concessão do remédio em hipóteses não previstas, mediante a utilização da chamada cláusula geral do Edito Perpétuo, quando sua autoridade se sobrepôs e acabou por absorver o imperium do Pretor.

Com a codificação do Edito Perpétuo e sua aprovação por um senatusconsulto, a antítese republicana ius honorarium - ius civile começa a desaparecer, na medida em que os antigos remédios pretorianos vão se processualizando sob $o$ influxo do novo sistema, que, originário das províncias, é transplantado para Roma, onde pelo espaço de três séculos

122. Cervenca, Studi Vari. cit. p. 64.

123. Dig. 4, 4.16, § 5: "Nunc videndum, qui in integrum restituere possünt. Et tam Praefectus Urbi, quam alii magistratus pro iurisdictione sua restituere in integrum possunt, tam in aliis causis, quam contram sententiam suam" Divergem os romanistas quanto à autenticidade desse texto, que BIóndi considera truncado, APPUntı, cit., p. 99, enquanto que LAURIA, Iurisdictio, cit., p. 522, n. ${ }^{\circ}$ 252, o considera genuino. Para Cervenca, Studi Vari, cit. p. 65, 66, a genuidade do texto, no que se refere à autoridade do Praefectus Urbi, é corroborada pelo fragmento de PAULo, pertinente à mesma época dos Severos, a demonstrar que a figura do Pretor é colocada em segundo plano com respeito ̀̀ autoridade do mais alto funcionário da cognitio extra-ordinem em Roma.

124. Dig. 4.4. 29§ 2; 4.4.42; Cod. 2.36.2; 2.46.1: 2.50.6: 2.52.2. 
coexistiu com o sistema do Ordo privatorum, até ser consagrado por uma Constituição do ano 294, no reinado de DIOCLECIANO.

Alguns importantes aspectos assinalam a diferença da r.i.i. pretória, do sistema do Ordo, da r.i.i. concedida pelos magistrados imperiais no sistema da cognitio extra-ordinem.

Em primeiro lugar, consoante o parecer de autorizados autores ${ }^{125}$, o Pretor podia conceder a r.i.i. inaudita altera pars, uma vez que a presença daquele contra quem se solicitava $o$ auxilium não era considerada obrigatória.

No século III, ULPIANo enuncia em seus Comentários a regra oposta: ... "Et puto tutius adversus utrumque; causa enim cognita et praesentibus adversariis, vel si per contumaciam desint, in integrum restitutiones perpendendae sunt". Dig. 4.4.13 pr.).

A inobservância dessa regra, responde Modestino, torna ineficaz em relação aos credores a r.i.i. concedida sem a sua citação, a qual não os pode prejudicar em nada; ... "quum non evocatis creditoribus in integrum restitutionis decretum interpositum proponatur, minime id creditoribus praeiudicasse." (Dig. 4.4.29 § 2).

A regra é consagrada em constituições de diferentes Imperadores :

... "Sed si etiamnum in ea aetate es, cui subveniri solet, aditus competens iudex, an te in integrum restituere debeat, praesente diversa parte causa cognita dispiciet". (Cod. 5.71.1) ... "si ad te hereditas sororis tuae vel bonorum possessio pertinuit, et tempora nondum praeterierit, intra quae legibus conceditur ex persona defuncti postulare in integrum restitutionem, praeses provinciae praesente diversa parte examinabit". (Cod. 2.34(33).1).

"Si omnes creditores praesentes sunt, ubi restitutio postulatur, a iudice vocentur, ut intersint, quum minor se abstinet. Sed si omnes absunt vel quidam, solemniter a iudice citentur." (Cód. 2.39). Esta constituição vem reproduzida por JUSTINIANo na Novela 119, const. 115 cap. 6: ... "si quidem omnes creditores praesentes fuerint in illis locis, in quibus in integrum restitutio postulatur, vocentur a iudice creditores, et

125. LAURIA, Iurisdictio, cit. p. 519; CARRELLI, Decretum e Sententia, cit., p. 181 . 
praesentibus omnibus ab huiusmodi hereditate se minores abstineant. Si vero omnes aut aliqui creditorum absentes fuerint, iubemos, minores volentes hoc agere locorum iudicem, in quibus ipsi degunt, adire, illum vero per consuetas citationes vocare creditores"...

Revelam esses textos que, no regime processual da cognitio extra-ordinem, para a concessão da r.i.i. era necessária a presença da parte que ia sofrer os efeitos da medida e, por isso, devia ser regularmente convocada a juízo, sendo essa exigência, desconhecida na República, um dos fatores do nivelamento do auxilium extraordinarium ao commune auxilium, quando o remédio pretoriano se transforma em iudicium.

A jurisdicização da r.i.i. que se opera na idade clássica, em razão do ordenamento judiciário imperial, importou na sua processualização, segundo o sistema da cognitio extraordinem, que se traduz na terminologia empregada nos textos, a revelar a equiparação do remédio às actiones, tais como: actio, causa, lis, sententia, iudicare, iudicatum ${ }^{126}$.

O efeito mais importante da jurisdicização é a transformação do auxilium em beneficium.

Enquanto auxilium, que conceditur para a tutela de estados de fato, considerados merecedores de proteção segundo a discricionária avaliação do Pretor, a r.i.i. é impetrada com um ato, praticado sem particular formalidade, indicado nas fontes com os termos postulatio, impetratio ou imploratio.

Em virtude de sua processualização, o provimento restitutório se configura como um beneficium que competit, ou seja, a r.i.i. assume as características de um direito, fundado sobre uma norma de ius singulare e destinado a paralisar o ius civile, que o interessado faz valer em juízo por meio de uma contestatio, que é o ato introdutório do procedimento no sistema da cognitio extra-ordinem ${ }^{127}$.

A r.i.i. então baseia-se em um direito subjetivo. Não é mais solicitada, é devida; não é mais um remedium que datur, porém um beneficium que competit ${ }^{128}$.

126. Cf. RAGGI, La Restitutio, cit., p. 83, nota 52 .

127. A respeito dessa evolução e respectiva terminologia, ver: CARRELLI, Decretum e Setentia, cit., p. 211 e segs.; Raggi, La Restitutio, cit. p. 50, 51; Cervenca, Per lo Studio, cit., p. 608 e Studi Vari, cit., p. 83-88.

128. Fabbrini, Per la Storia, cit., p. 226. 
10. Não padece dúvida ter sido o processo civil o campo em que ocorreram as mais freqüentes e significativas intervenções do auxilium extraordinarium do Pretor, para desfazer erros e omissões lesivos do direito de um dos litigantes, que eram irremediáveis segundo as formas rigorosas do antigo processo.

É que o auxílio do Pretor, por motivo de eqüidade, era prestado não só nos casos de lesão decorrente de atividade regida pelo ius civile, mas também, como disse UlPIANo, "sed et in iudiciis subvenitur, sive dum agit, sive dum convenitur, captus sit". (Dig. 4.4.7 § 4).

Na idade clássica, os motivos de restituição previstos no Edito (Dig. 4.1.1. e 2) são os mesmos, tanto para a restituição contra um ato jurídico qualquer, como contra ato do processo em juízo, inexistindo qualquer distinção nos textos.

Diversa era, porém, a situação do interessado na concessão da r.i.i., conforme se tratasse de maior ou de menor de 25 anos.

Ao menor bastava a prova da sua condição e do prejuízo sofrido. A menoridade constituía uma questão prejudicial a ser provada e decidida antes da concessão da restitutio, como se verifica deste passo de ScEvola: "Intra utiles tempus restitutionis apud Praesidem petierunt in integrum restitutionem minores, et de aetate sua probaverunt; dicta pro aetate sententia, adversarii, ut impedirent cognitionem Praesidis, ad Imperatorem appellarunt;" ... (Dig. 4.4.39)

Do maior, além da prova do prejuízo era exigido que provasse a ocorrência do motivo alegado para a restituição; a idade, quando questionada, deveria ser provada, em razão da consequiência prejudicial para a restituição, segundo informou MARCELO: "De aetate eius, qui se maiorem annis vigintiquinque dicit, causa cognita probandum est, quia per eam probationem in integrum restitutioni eiusdem adolescentis et aliis causis praeiudicatur". (Dig. 4.4.43)

Desde que lesivo do direito de uma das partes em juízo, a r.i.i. podia ser impetrada contra qualquer ato do processo com fundamento em um dos motivos de eqüidade relacionados no Edito, ou com fundamento na chamada cláusula geral, quando não estivesse previsto mas houvesse uma outra justa causa para a concessão.

As hipóteses mais freqüentes do auxilium quanto a atos do processo constumavam ser de restituição contra a redação 
da fórmula, contra os efeitos da litiscontestatio e contra o próprio julgamento da lide.

Em vista dos comentários de Ulpiano, do livro 13 ad. Edictum, concernentes aos vários casos de restituição da lide quanto ao efeito extintivo da litiscontestatio, que os compiladores transcreveram no DIGESTo, LENEL ${ }^{129}$ inferiu que o Edito deveria ter um título específico a respeito, que é na sua reconstituição o § 45 "De Litibus Restituendis", e, muito embora os compiladores não tenham reproduzido todos os respectivos textos que ele conjectura existirem no Edito, nem tenham reunido sob esse título os poucos que transcreveram, ele o fez decididamente, escrevendo: "Quoiqu'il en soit, nous sommes autorisés à réunir, en cet endroit de l'édit, tous les renseignements épars qui nous ont été transmis sur les cas de restitution d'actions éteintes para suite de leur déduction en justice."

Charvet ${ }^{130}$, partindo das observações de Lenel e de outros romanistas que assinalaram diversos textos referentes a casos análogos, passou em revista as várias situações em que o Pretor prestou o auxilium extraordinarium contra o efeito extintivo da litiscontestatio, notadamente os casos da ação de pecúlio e outras adjectitiae qualitatis, ressaltando, entretanto, que os exemplos examinados não devem fazer crer que as ações adjectitiae qualitatis sejam as únicas nas quais uma aplicação rigorosa do processo civil parece contrário à eqüidade. "Ce sont les erreurs commises dans la rédaction de la formule, qui ont entrainé les plus courantes mesures de rescision basées sur l'injustice de l'effet extinctif de la litiscontestatio" ${ }^{131}$.

Deve-se a GAIo ${ }^{132}$ a indicação das regras do direito clássico sobre os erros da fórmula ou a omissão de uma exceptio, (Inst. IV, 53, 57, 125), que só podem ser corrigidos mediante a r.i.i. concedida pelo Pretor, sendo que Justiniano, ao propósito, para permitir a restituição aos maiores, em caso de erro, subordina-a à importância da causa e a um justo erro. "Sane si tam magna causa iusti erroris interveniebat, ut etiam constantissimus quisque labi posset, etiam maiori vigintiquinque annis succurrebatur"; (Inst. IV.6. § 33)

129. LENEL, op. cit. v. I, p. 142.

130. Charvet, op. cit., p. 86.

131. Charvet, op. cit., p. 90.

132. sobre a hipótese de que trata GAIO IV -53 , ver a profunda investigação histórica de RICCARDo ORESTANo Plus petitio e In Integrum Restitutio nos Studi in Onore di Biondo Biondi, cit., v. 2, p. 229. 
Aliás, o jurisconsulto PaULo indica o iustum errorem como um dos motivos gerais da r.i.i. (Pauli Sententiarum, 1.7.2: Dig. 4.1.2.)

Todavia, como as conseqüências do erro seguidamente se confundiam com as do medo e do dolo, a partir dos meados da idade clássica aquele vício, ao que parece, não constituia mais um motivo autônomo de r.i.i. e somente era invocado, independentemente do medo ou do dolo, em casos especiais, em que o erro se revestia daquele aspecto de iustum errorem, de que falou PAULO e foi repetido por JUSTINIANO.

Consoante a ponderada apreciação de CHARVET ${ }^{133}$, concebe-se que o Pretor tenha experimentado uma certa hesitação em socorrer as vítimas de um simples erro, e não tenha realizado senão uma assimilação incompleta do erro com as outras causas gerais da r.i.i.

Já na segunda metade do último século da República as r.i.i. $o b$ metum e $o b$ dolum teríam sido substituídas pelas actio quod metus causa e actio de dolo malo, que, em determinadas circunstâncias, substituíram, também, a r.i.i. $o b$ errorem.

Quando o erro ou omissão processual fosse devido à fraude da parte contrária, a concessão do auxilium para a restituição da lide, segundo as exigências da razão e da eqüidade, era dever do bom Pretor, em vez de dar lugar à ação infamante de dolo malo, que também cabia, como ponderou Marcelo: "Nec intra has solum species consistet huius generis auxilium; entenim deceptis sine culpa sua, maxime si fraus ab adversario intervenerit, succurri oportebit, quum etiam de dolo malo actio competere soleat. Et boni Praetoris est potius restituere litem, ut et ratio et aequitas postulabit, quam actionem famosam constituere, ad quam tunc demum descendendum est, quum remedio locus esse non potest." (Dig. 4.1.7 § 1)

Para reparar o prejuízo causado por um ato doloso o Pretor concedia ao lesado a ação infamante de dolo malo, mas se o dolo tivesse se verificado no curso do processo, em juízo, mais indicado era que o Pretor restituisse a lide ao estado anterior, como se o ato doloso não tivesse ocorrido, restabele-

133. Charvet, op. cit., p. 93. Sobre o problema do erro ver as monografias de VocI, L'errore nel diritto romano, Milão 1937, p. 234-240, e de UGo ZILLETTI, La dottrina dell'errore nella storia del diritto romano, Milão 1961, p. 167. 
cendo-se para os litigantes a situação jurídica em que se encontravam antes ${ }^{133 a}$.

Dentre todas as formas de restituição contra atos do processo em juízo, a mais importante, verdadeiramente, é a que era concedida contra a sentença ${ }^{134}$.

Encontram-se no Digesto numerosos textos a respeito, mas, todos pertinentes à idade clássica, ou seja, ao período em que os dois sistemas processuais do Ordo iudiciorum privatorum e da Cognito extra-ordinem coexistiram lado a lado, por vários anos, até que este último suplantou aquele e se tornou oficial (294 dC.) e levou à abolição das fórmulas (342 dC.), já no Baixo Império.

Por falta de indicação dos jurisconsultos que os escreveram, se os mesmos diziam respeito a sentenças proferidas segundo o sistema do Ordo, ou se extra-ordinem, torna-se bastante difícil situar com precisão esses textos em relação aos sistemas, mesmo quando neles él indicado expressamente "s Magistrado, porque durante o Principado, até ao advento do Dominato com Diocleciano, coexistiram em Roma juntamente com os Pretores, URbano e PeREgrino de origem republicana, os Praefectus Urbi e Praefectus Praetoreo, criados pelo Imperador e dotados de poderes jurisdicionais, notadamente quanto à concessão da r.i.i. (Dig. 4.4.16 § 5; 4.4 .17 e 1.11 § 2) ; sendo de lembrar-se que Salvio Juliano, o codificador do Edito Perpétuo, foi Pretor e Praefectus Urbi, ao tempo de AdRIano, Papiniano foi Prefeito do Pretório sob Septimio Severo, Ulpiano e PaUlo foram Prefeitos do Pretório sob ALEXANDRE SEVERO.

Outro ponto gerador de incerteza é a referência, em vários desses textos, ao recurso da apelação ao Imperador, que, segundo uma autorizada doutrina ${ }^{135}$, teve sua origem no sistema da cognitio extra ordinem, o que levaria à conclusão de serem as questionadas sentenças pertinentes a esse sistema.

133a. A propósito do alcance do texto de MARcelo, ver as considerações de M. BRUTTI, La problematica del dolo, cit., v. II, p. 333 a 335, notas 7 e 8 e p. 447; e Nrcola Palazzolo, Potere Imperiale ed Organi Giurisdizionali nel II secolo DC, Milão 1974, p. 187 a 189, notas 162, 163.

134. SavignY, op. cit., v. 7, p. 157; GiUSEPPE Bianchini, Restitutio in Integrum, na Enciclopedia Giuridica Italiana, v. XIV, parte II, Milão 1906, p. 198.

135. Orestano, L'APPello cit., 186. 
O argumento, entretanto, não é absoluto, em vista da demonstração feita por PERRoT ${ }^{136}$, de que em alguns casos, a apelação ao Príncipe dizia respeito a lides que teriam sido julgadas segundo o regime processual do Ordo.

Dentro dessa ordem de idéias, os textos de Paulo (Dig. 4.4.46) e de Modestino (Dig. 4.4.29 pr. e § 1) desafiam sua filiação a qualquer dos dois sistemas; os de PAPINIANo (Dig. 4.4.30), de MARCELo (Dig. 4.1 .8 pr. e $\$ 1$ ) e de PAUlo (Dig. 34.2.35) que fazem expressa referência ao Pretor, não podem ser atribuídos com segurança ao sistema do Ordo, apenas por aquela indicação, como, do mesmo modo não se pode ter por indubitável que os textos de ULPIANo ( $D i g .4 .4 .16$ $\S 5 ; 4.4 .18$ ) de HERMOGENIANo (Dig. 4.4.17) de CALISTRATo (Dig. 42.2.33) digam respeito ao sistema extra-ordinem, tão somente pela circunstância de nomearem o Prefeito da Cidade, o Prefeito do Pretório e o Imperador, e, também, quando o jurisconsulto se refere ao recurso da apelação, (MACRo, Dig. 4.1.9), isso não significa, de modo absoluto, que o texto se reporte a uma sentença extra-ordinem.

A despeito da insegurança, os intérpretes, de modo geral, tendem para a conclusão de que esses textos dizem respeito a julgamentos que foram proferidos extra-ordinem, por ser este o sistema processual que vinha se impondo aos litigantes, na idade dos Severos, quando os mesmos foram escritos.

Na República, em face do testemunho de CícERo, tem-se como certo que o Magistrado e o Senado concediam a restituição contra os julgamentos iníqüos, como vimos anteriormente, autorizando a instauração de novos iudicia.

$\mathrm{Na}$ idade clássica, ao ver de BIoNDI ${ }^{137}$ a restitutio atinge a base mesma do juízo, isto é, a litiscontestatio e conseqüentemente cai também o iudicatum. Mas, "una restitutio contra la sententia del magistrado non era questione che si potesse presentare alla mente di un giurista classico". Ao contrário, agora que a litiscontestatio não é mais um ato, mas antes um momento processual, a restitutio atinge desde logo

136. ERnest Perrot, L'Appel dans la procédure de l'Ordo Jüdiciorum, Paris 1907 , p. 35 e segs., 85 e segs.; ver também LUIGI RAGGI, Studi sulle impugnazioni civile nel processo romano, cit., p. 7 .

137. Biondi, Appunti cit., p. 97. Segundo Palazzolo, nel caso di restitutio contra sententiam, poi, siamo in presenza di un vero e proprio mezzo di gravame, del tutto sconosciuto al sistema dell' Ordo", op. cit., p. 182, nota 147. 
a sentença, como nas clássicas cognitiones, escreve o famoso romanista, referindo-se ao processo extra-ordinem.

Em posição oposta se situa o primoroso trabalho de RAGGI ${ }^{138}$. Analisando a r.i.i. como instrumento que nos seus delineamentos processuais aparece originariamente correlacionado com as exigências e as características do Ordo - "basta pensare ch' é sostanzialmente l'unico strumento apprestato in quel sistema per far valere attivamente vizi formali o sostanziali della sentenza" - conclui que a restitutio pretória, na sua ordenação mais remota, realiza de fato uma ciente ruptura da legalidade formal, justamente porque não existe a possibilidade do reexame (e eventualmente da reforma) do pronunciamento judicial.

De todos os remédios que se conheciam nesta matéria, assinalou ORESTANO ${ }^{139}$, o único que fosse dirigido diretamente contra a sentença era a restitutio in integrum, que não somente nasce e se mantém por toda a idade clássica como um remédio de caráter excepcional (extraordinarium auxilium a chama ainda ULPIANo no Dig. 4.4.16 pr.) mas vinha concedida em hipóteses (violência, dolo, idade das partes, erros destas e assim por diante) que não diziam respeito diretamente ao mérito do juízo. Portanto, se o processo tinha se constituído e desenvolvido regularmente sem causas perturbadoras, a sentença que o concluía era subtraída a toda e qualquer possibilidade de anulação, revogação ou revisão.

A admissão da possibilidade de qualquer impugnação à sentença validamente pronunciada repugnava aos princípios estruturais de todo o sistema do Ordo iudiciorum privatorum. Mas, por outro lado, a sentença nula por vício de forma era considerada juridicamente inexistente. Ao condenado abriam-se duas vias para contestar a existência válida do julgado: a enfitiatio, de caráter defensivo, por ocasião do exercício da actio iudicati pelo credor, e a revocatio in duplum, de natureza ofensiva que podia ser proposta pelo condenado contra o credor, antes da actio iudicati, mas, cuja presença na idade clássica não é demonstrada com segurança, pelo que não é admitida pacificamente. ${ }^{140}$.

138. RAGGI, La Restitutio cit., p. 41 e 118.

139. ORESTANo, op. cit., p. 116.

140. Cf. a primeira parte deste trabalho, na Rev. da Faculdade de Direito da U.S.P., 1977, v. $72-10^{\circ}$ f., p. 359 a 375. 
Do exame das fontes não resulta que a r.i.i. tivesse tido aplicação contra o julgado nulo, mas, tão somente contra os efeitos iníqüos de julgados formalmente válidos.

$O$ fundamento da restitutio praetoria é sempre a eqüidade. Nem a nulidade formal, nem a injustiça substancial do iudicatum levaram o Pretor a conceder o auxilium extraordinarium contra as sentenças.

11. No principado, com a oficialização da appellatio, como remédio ordinário contra a injustiça substancial do julgado resultante de sentenças formalmente válidas, ao lado da r.i.i. como auxilium extraordinarium que o Pretor e depois o Imperador e os Magistrados imperiais podiam conceder contra tais sentenças, pelos motivos de eqüidade acolhidos no Edito Perpétuo, verifica-se a ocorrência da recíproca inserção da appellatio na r.i.i. e desta na appellatio, que vem sendo minuciosamente examinada por modernos romanistas ${ }^{141}$.

Documentam as fontes que o interessado podia apelar para o Imperador contra a decisão do Pretor ou do Praefectus Urbi denegatória da r.i.i.l (Dig. 4.4 .38 pr), bem como contra a concessão da restitutio (Dig. 4.4.39)

Assim, os efeitos da inserção da appellatio na r.i.i. resultam em desvantagem do auxílio pretoriano e na sua descaracterização, pela sujeição do Pretor à magistratura imperial e pela assimilação do seu provimento a qualquer outro, considerado reexaminável pelo Imperador como todos os demais proferidos pelos Magistrados burocráticos no sistema extra-ordinem.

Quanto à inserção da r.i.i. no processo da appellatio, em primeiro lugar destaca-se a função de integração ou de correção, de natureza subsidiária, por motivo de eqüidade, para abrandar o rigor dos princípios processuais a respeito daquele meio ordinário de impugnação das sentenças, com a finalidade de possibilitar o reexame, que é a função primária da appellatio.

Uma das nervaturas essenciais do instituto da appellatio, que a legislação imperial cuida de fixar, especialmente na idade dos Severos, é a da inderrogabilidade do tempus appelandi, para que esse remédio não degenere em instrumento de arbítrio e de desordem ${ }^{142}$. Como disse UlPIANo, "et qui tempora praefi-

141. RAGGI, La Restitutio, cit., p. 118 e segs.; FABBRINI, op. cit., p. 220.

142. ORestano, op. cit., p. 256; FabBrini, op. cit., p. 222; RAGGI, La Restitutio, p. 143 e Studi sulle impugnazioni, p. 59. 
nita in ordinem eiusmodi appellationum peragendo non servaverint, merito praescriptione repelluntur" (Dig. 50, 5.1. pr)

O caso mais simples de utilização da r.i.i. no processo da appellatio é o da restitutio do ius appellandi, que importa em derrogação do rígido princípio da improrrogabilidade do termo para apelar.

O benefício era concedido em duas hipóteses excepcionais: em favor do menor de 25 anos (Dig. 4.4.7.11) e do ausente republicae causa, que foi representado em juízo por procurator que não apelou da sentença contra ele proferida (Dig. 4.1.8)

Entre os menores de 25 anos e os que estão ausentes por causa da República, há esta diferença, esclarece o jurisconsulto MACRo, que os menores, ainda os que foram defendidos por seus tutores ou curadores, são, não obstante, restituídos por inteiro "contra Rem publicam", bem que com conhecimento de causa; mas ao ausente por causa da República, e também os demais que se compreendem no mesmo caso, se foram defendidos por seus procuradores costuma-se auxiliá-los com a restituição somente para que se lhes permita apelar. (Dig. 4.1.8)

Na expressão "contra Rem publicam" os glosadores identificaram a r.i.i. "contra rem iudicatam", ou seja contra a sentença ${ }^{143}$.

A diferença residia então nos efeitos da r.i.i. que, para os menores, atingiam a própria sentença, em consonância com a regra estabelecida para a restituição contra as sentenças dos Presidentes das Províncias (Dig. 4.4.42) em razão do benefício da idade, ao passo que para os ausentes, se limitavam à restituição do prazo para apelar.

Aliás, a restituição do prazo para a apelação dos menores estava prevista, expressamente, em outro texto (Dig. 4.4.7 § 11).

Na restitutio do ius appellandi a r.i.i. exerce uma função subsidiária, de correção equitativa do rigor da lei, em favor dos menores e dos ausentes.

A concessão de dois distintos gêneros de restituição em favor dos menores, revela a graduação entre os dois modos de inserção da r.i.i. no processo da appellatio: como auxiliar e instrumental, no caso da restitutio do ius appellandi, e como

143. RAGGI, La Restitutio, cit., p. 144, nota 42 . 
substitutiva da própria appellatio, no caso da restitutio contra sententiam ${ }^{144}$; pois, segundo ULPIANo, o que os maiores conseguem com a apelação os menores conseguem com a restituição: "Praeses Provinciae minorem in integrum restituere potest etiam contra suam, vel decessoris sui sententiam; quod enim appellatio interposita maioribus praestat, hoc beneficio aetatis consequuntur minores". (Dig. 4.4.42) ${ }^{145}$.

Sem dúvida, a partir do período histórico em que a appellatio é estruturada como o meio ordinário de impugnação da sentença, com a finalidade de provocar um novo julgamento da lide, em instância superior, e, assim, a eventual reforma do julgado, a utilização da r.i.i. "contra sententiam", como substitutiva da appellatio, torna-se muito reduzida, mas não desaparece de todo.

Uma das hipóteses mais relevantes é a da concessão da r.i.i. contra a sentença proferida em grau de apelação, ou seja, depois de exaurida a competência dos magistrados burocráticos segundo o nível da hierarquia.

Em tais casos, o Imperador não somente se reserva a faculdade de conceder a restitutio sucessiva à appellatio (Dig. $\left.4.4 .18 \S 3 .^{\circ}\right)$ - "insolitum esse, post sententiam vice sua ex appellationem dicta alium in integrum restitutionem tribuere, nisi solum Principem" - mas, como acentuou UlPIANo, ainda de tal faculdade se valia "perraro", particularmente quando a sentença tivesse sido proferida por ele: "Sin autem Princips sententiam dixit, perraro solet permittere restitutionem (Dig. 4.4.18 § $10^{\circ}$ ).

De igual modo o Imperador se reservava a competência para a concessão da r.i.i. contra as sentenças pronunciadas vice sacra e as dos iudices dati, que tivessem julgado por delegação como seu procurador: "nam adversus eius sententiam, qui vice principis cognovit, solus princeps restituet" (Cod. 2.26.3) "Princeps enim solus contra sententiam procuratorum suorum in integrum restituere solet" (Cod. 2.46.1).

A partir da constituição do Imperador Constantino, do ano 331, ficou proibida a apelação contra as sentenças proferidas pelo Prefeito do Pretório (Cod. Th. 11.30.16), que se

144. RAGGI, op. cit., p. 147.

145. A interpretação desse texto deu margem às mais "encarniçadas" divergências doutrinárias - a expressão é de RAGGI, que examina as diferentes opiniões e emite a sua, p. 160-169. 
tornou o verdadeiro substituto do Imperador no terreno jurisdicional, e, que, por sua dignidade e sabedoria, não haveria de julgar de outro modo como o faria o próprio Imperador. (Dig. 1.11.1. § $10^{\circ}$ ).

Ao vencido e inconformado com a sentença do Prefeito do Pretório, contra a qual não era permitido apelar, foi concedida a faculdade de se dirigir ao Imperador por meio da "supplicatio", instituto de origem imperial, com a natureza de recurso extraordinário ${ }^{146}$, criado, ao que parece, pelos Imperadores TEODósio e VALENTINIANo, em 439, na constituição recolhida no Código de Justiniano, Livro 7, Título 42, que dispõe sobre as sentenças do Prefeito do Pretório, onde se declara, "si contra ius se laesos affirment, non provocandi, sed supplicandi licentiam ministramus".

Àquela mais alta autoridade da hierarquia judiciária imperial era atribuída, também, em caráter excepcional, competência para rever suas sentenças, mediante o auxílio da retratação introduzido pelo Imperador, $(\operatorname{Cod}$. 7.62 .35 e Novelas 82.C.12 e 119.C.5), o que era vedado aos demais magistrados.

De par com a retratação, assistia-lhe o poder de conceder a r.i.i. contra sua própria sentença (Dig. 4.4.17), o que era considerado como um outro seu privilégio, "Subnixi sunt etiam alio privilegio Praefecti Praetorio, ne a sententiis eorum minores aetate ab allis magistratibus nisi ab ipsi Praefectis Praetorio restitui possint" (Dig. 1.11.1 § 2. ${ }^{\circ}$ ).

A explicação da razão jurídica da diversidade que se verificava em relação à sentença do Prefeito do Pretório, contra a qual não era permitido apelar mas se autorizava a concessão da r.i.i., foi dada por HERMOGENIANO:

Os Prefeitos do Pretório podem, também, restituir por inteiro contra sua sentença, ainda que deles não se possa apelar. $\mathbf{E}$ isto é assim tão diverso, porque, verdadeiramente a apelação contém queixa da injustiça da sentença, porém a restituição por inteiro petição de vênia do erro próprio, ou alegação do engano causado pelo adversário. (Dig. 4.4.17)

$O$ texto assinala a importante diferença quanto ao escopo de cada um desses institutos, que, no dizer de HENRI AUBERT ${ }^{147}$, é o que explica porque a r.i.i. não foi inteiramente absorvida

146. Scialoja, Procedura, cit.., p. 308; Humberto Cuenca, Processo Civil Romano, Buenos Aires 1957, p. 162.

147. HENRI AUbert, op. cit., p. 8. 
pela appellatio. Segundo esse autor, pode-se caracterizar os dois institutos dizendo que a apelação corrige a injustiça do julgamento, em consideração à lei; a restituição, o rigor da lei, em consideração aos fatos da causa.

Essa marcante diferença entre a appelatio e a r.i.i. levou BETHMAN - HollWEG ${ }^{148}$ a dizer que, por meio da apelação fazia-se valer a injustiça objetiva do julgamento, e, por meio da r.i.i. sua injustiça subjetiva.

Entre a appellatio e a r.i.i. encontra-se firmada, também, importante regra diferenciadora, de natureza processual, quanto à competência do órgão judicial, pois, enquanto a apelação deve ser submetida e julgada por um magistrado de hierarquia superior ao que proferiu o julgamento impugnado, a r.i.i. é impetrada perante o magistrado que decidiu e que poderá concedê-la contra a sua decisão.

A diferença fundamental entre a r.i.i. que, mesmo no Império, conservou a qualidade de auxilium extraordinarium, e a appellatio, que PAPINIANo configurou como auxilium commune (Dig. $46.8 .3 \S 1 .^{\circ}$ ) reside no efeito específico de cada um desses remédios.

A concessão da r.i.i. produz sempre e unicamente a revogação da sentença. Efeito rescisório típico. Convém ter presente o fato da processualização do antigo remédio pretoriano, com sua absorção pelo sistema das ações, que se opera no regime da cognitio extra-ordinem, e que conduz ao iudicium rescissorium perante o mesmo magistrado que proferiu o julgamento.

A apelação, ao contrário, provoca o reexame da sentença apelada por um órgão judicial hierarquicamente superior, com a realização de novo julgamento da lide e a emissão de uma nova sentença.

Em razão do novo julgamento, a sentença proferida sobre a apelação pode ser no sentido de confirmar a sentença impugnada, quando o recurso é rejeitado, ou de reformá-la, quando a impugnação é acolhida. Neste caso, o novo julgamento substitui o anterior. A reforma, entretanto, pode ser

148. BethmanN-HollWEg, Geschichte Römischen Recht, t. II, p. 714, nota 18, citado por HeNRI Aubert, op. cit., p. 9, nota 2. No mesmo sentido SAvigny, op. cit., v. 7 , p. 159 , nota t. 
modificativa, quando altera os efeitos substanciais do julgado, quantitativos ou qualitativos, ou cassatória, quando nega qualquer efeito à sentença, que é, então, revogada.

A revogação da sentença pela appellatio ocorre quando, no juízo da apelação, é julgada procedente a ação que a sentença rejeitou, ou improcedente a que a sentença acolheu.

No período histórico em que em sua maior parte os motivos de restituição, codificados no Edito Perpétuo, passam a ser tutelados por ações próprias, o efeito revocatório da appellatio torna-se análogo ao da restitutio in integrum.

Figure-se uma actio de dolo malo, ou quod metus causa, que tenha sido julgada procedente, ou improcedente, pela sentença. $\mathrm{O}$ acolhimento da correspondente appellatio equivale à concessão ou recusa da r.i.i.

Aliás, o reconhecimento desse efeito da apelação, mesmo em relação à própria restitutio in integrum, é proclamado enfaticamente em uma constituição do tempo dos Severos, recolhida no Código de Justiniano, 2.43.1: "Se após a sentença do Pró-Cônsul, dada contra vós, pretendestes ser restituído por inteiro e não o conseguistes, em vão pretendeis que essa questão da restituição por inteiro seja agitada de novo; pois, devíeis apelar se a sentença vos desagradou. Mas, se estais na idade em que se costuma auxiliar, restituimo-vos o direito de apelar" ${ }^{149}$.

Coexistindo com a appellatio, o campo de aplicação da r.i.i., como remédio extraordinário contra as sentenças, restringe-se a poucas hipóteses, em caráter excepcional, quando as exigências de justiça, e notadamente as de eqüidade, não tenham sido satisfeitas com a utilização do meio ordinário de impugnação.

Para impedir que os dois remédios venham a ser empregados em regime de concorrência, procura-se estabelecer uma ordem de prejudicialidade entre ambos, no sentido da admissão da r.i.i. após a exaustão do iter processual da appellatio ${ }^{150}$.

149. "Si post sententiam proconsulis contra vos latam desiderastis in integrum restitui, nec obtinuistis, frusta ut rursus ea questio in integrum restitutionis agitetur, desideratis; appellare enim debuistis, si vobis sententia desplicebat. Sed si adhuc in ea aetate estis, cui subvenire solet, appellandi ius vobis restituimus".

150. Cf. Fabbrini, op. cit., p. 222. 
Entende FABBRINI ${ }^{151}$ que, quanto mais a apelação é favorecida no curso do Império, tanto mais a restitutio é confinada à condição de um instituto meramente auxiliar.

Contra essa conclusão pode-se antepor o fato histórico de a r.i.i., como remédio extraordinário, haver permanecido até o direito justinianeu com os mesmos pressupostos estabelecidos pelo direito clássico ${ }^{152}$, muito embora com sua aplicação limitada aos casos da minoridade e da ausência ${ }^{153}$.

Entre os casos estudados de utilização da r.i.i. como remédio extraordinário contra sentença já passada em julgado, em pleno Império, onde seu emprego é objetivado para o fim específico de revogação da sentença, e não como meio auxiliar, podem ser invocadas as situações a que se referem os textos do Dig. 42.1.33, 42.1.35 e do Cod. 7.52.4. Trata-se da concessão da r.i.i. contra a sentença baseada sobre falsa prova (Dig. 42.1.33), ou por terem sido descobertos novos documentos (Dig 42.1.35 e Cod. 7.52.4).

Casos de extrema gravidade, que evidenciam a excepcionalidade do recurso à r.i.i. e se enquadram entre os que o Imperador "perraro" admitia, para a concessão do remédio.

A respeito da restituição concedida pelo Imperador contra uma sentença baseada em falsa prova, especificamente no falso testemunho de testemunhas corrompidas por dinheiro, não ocorre qualquer dúvida, em face dos termos explícitos do rescripto de ADRIANo transcrito no Digesto: "Divus Adrianus aditus per libellum a Julio Tarentino, et iudicante eo falsis testimoniis, conspiratione adversariorum testibus pecunia corruptis religionem iudicis circunventam esse, in integrum causam restituendam in haec verba rescripsit: "Exemplum libelli dati mihi a Julio Tarentino mitti tibi iussi; tu, si tibi probaverit, conspiratione adversariorum et testibus pecunia corruptis oppressum se, et rem severe vindica, et si qua a iudice tam malo exemplo circunscripto iudicata sunt, in integrum restitue" (42.1.33).

Já a hipótese da restituição contra sentença transitada em julgado, por terem sido descobertos novos documentos que induzem a presunção de que em face deles o julgamento poderia ser outro, não é admitida pacificamente pelos roma-

151. FabBRINI, op. cit., loc. cit.

152. P. DE Franciscr, Sintesis Histórica del Derecho Romano, cit., p. 795.

153. Cf. Cervenca, Studi Vari, eit., p. 192. 
nistas tendo em vista os textos existentes cuja interpretação dá ensejo à divergência doutrinária, como a que se verifica, por exemplo, entre GLÜCK e seu tradutor e anotador LANDUCCI.

Os Imperadores ANTONINo (MARCo AURÉlio) e VERo (LÚCio) disseram em um rescripto que, embora não se devam restituir os juízos pela descoberta de novos documentos, não obstante, em um juízo público, havendo justa causa, deve permitir-se o uso de tais documentos (Dig. 42.1.35).

O Imperador GoRdiano disse numa constituição que é grave, por exemplo, que sob pretexto de novos instrumentos descobertos depois, se restaurarem os assuntos julgados ("Sub specie novorum instrumentorum postea repertorum res iudicatas restaurari, exemplo grave est" Cod. 7.52.4).

E o jurisconsulto PRISco NERÁcio deixou escrito que já não importa por que razão alguém crê que aquela ação lhe compete, do mesmo modo como se alguém houvesse encontrado novos documentos para sua causa, depois de haver sido julgada contra ele. (" . nec iam interest, qua ratione quis eam causam actionis competere sibi existimasset, perinde, ac si quis, posteaquam contra eum indicatum esset, nova instrumenta causae suae reperisset" Dig. 44.22.7).

Nas pegadas de HELlFELD ${ }^{153 a}$, o autor que vem seguindo, GLÜCK ${ }^{154}$ examinou a questão da possibilidade da r.i.i. contra a sentença transitada em julgado, por terem sido descobertas novas provas, e declara que, em se tratando de causa pública, concernente ao interesse do Estado, a restituição contra rem iudicatam tem lugar, por força das expressas palavras da lei, da mesma maneira como na restituição em favor dos menores (Cod. 2.26.5; 2.43.2).

Nas causas do interesse privado de maiores, lembra que muitos jurisconsultos (PUFFENDORF, LEYSER, SENCKENBERG) negam que se possa impetrar a r.i.i., e essa opinião parece

153a. AUgusti HeLlFeld, Jurisprudentia Forensis secundum Pandectarum Ordinem in usum auditorii proposita, cura Gottl. Euseb Oeltze, Editio Tertia, JENAE, 1796, p. 697, § 1972: "Rescindi tamen potest sententia per modum restitutionis in integrum, si 1) ex falsis instrumentis vel testimoniis lata ( $\$ 345)$ e), 2) publicum interesse laedit, f), 3) ex iureiurando purgatorio vel suppletorio falso lata ( $\$ 814) 4$ ) instrumenta per adversarium subtracta non nisi post sententiam reperiri potuerint g) 5) alia iusta causa restitutioni locum faciens adsit ( $\$ 436) . "$

154. GLücK, op. cit., v. 4, p. 8 a 10. 
fortalecida por diversas leis (Dig. 42.1.35 e Cod. 7.52.4) cujos textos transcreve. Mas, acrescenta GLÜCK, não se pode deduzir sem mais nada que a restituição seja inadmissível para os maiores, ainda quando exista um justo motivo. Acontece, alguma vez, que não tenha sido possível descobrir as provas, encontradas somente mais tarde, por dolo do adversário, ou as provas mesmas possam ter revelado o dolo; podese dar o caso que, sem malícia do adversário, tenha sido impossível ante rem iudicatam ter notícia de certas provas, descobertas só mais tarde, de onde resulta induvidoso o direito do sucumbente; então, como em bom direito pode-se dizê-lo prejudicado sem culpa, não se poderia negar-lhe a restituição sem violar a eqüidade. A este modo de ver não se opõem as leis referidas, como as que se limitam a negar a anulação de um válido juízo $o b$ sola noviter reperta instrumenta; elas não excluem o caso de um justo motivo de restituição.

LANDUCCI ${ }^{155}$ entende que GLÜCK sofismou, porque no direito romano não há a r.i.i. ob noviter reperta. Os dois textos citados são mais decisivos do que pareceram a GLÜcK, e há, ainda, o texto clássico de Nerácio, que ele omitiu. Assim, nos casos aventados por GLÜCK, entende LANDUCCI que se deva falar da r.i.i. propter dolum, e da r.i.i. propter errorem.

Examinando a questão em face dos fragmentos de NERÁcIo e de GoRdiano, que transcreve em sua exposição, COGLIOLO ${ }^{156}$ sustenta que, se a primeira sentença fundou-se em documentos falsos ou viciados, ou se os documentos verdadeiros, encontrados depois por uma parte, tinham estado escondidos dolosamente pela outra, o defraudado pode valer-se de uma restitutio in integrum, que nisso se assemelha um pouco ao juizo de revogação do direito italiano.

Para comprovar que a r.i.i. no Império, após a estruturação da appellatio como remédio ordinário contra a sentença, estava reduzida aos limites da excepcionalidade, uma vez que o Imperador não somente se reservava a faculdade de conceder a restituição sucessiva à apelação, como de tal faculdade se prevalecia "perraro", RAGGI ${ }^{157}$ invoca os textos do Dig. 42.1.35 e do Cód. 7.52.4, e, depois de considerar a hipótese da descoberta de novos elementos de prova após a sentença já transi-

155. LaNdo LANDUCCI, in Glück, op. cit., p. 9, nota $a$.

156. Pietro Coglolo, Trat. Teorico e Pratico della Eccezione di Cosa Judicata, Turim 1883, p. 485.

157. RAGGI, op. cit., p. 155 , nota 59. 
tada em julgado, afirma, incisivamente, ser claro que, na situação a que se referem tanto o rescrito dos divi Frates quanto o de GoRDIANo, a aplicabilidade do instituto restitutório se justifica precisamente porquanto os dois típicos critérios do processo cognitório (a apelação e o princípio de nulidade) são absolutamente inoperantes e não aplicáveis.

12. A apelação reflete o espírito de uma sociedade burocratizada, dominada pelo culto da norma abstrata e pelo princípio de autoridade, que emerge da geral e profunda transformação do sistema processual que o Principado primeiro e a Monarquia absoluta depois introduzem no ordenamento jurídico romano, levando no plano normativo a produção do direito a uma progressiva concentração nas mãos do Imperador, e no plano processual à estatização da justiça, ordenada dentro de esquemas de aparato administrativo em graus superpostos, que tendem a se reunir, igualmente, nas mãos do Imperador, colocado no vértice da hierarquia ${ }^{158}$.

A restitutio in integrum, que sobrevive na Monarquia absoluta, perde naturalmente o caráter originário de meio complementar do sistema do Ordo iudiciorum privatorum, fundado no imperium do Pretor, para transformar-se, no sistema extraordinem, em um procedimento semelhante ao das ações.

Mesmo nos casos excepcionais em que ainda continuou tendo aplicação, conservando sua precípua finalidade, na idade post clássica a r.i.i. é definida como uma ação.

Ação destinada a reintegrar a coisa ou a causa em seu estado anterior, como se lê na conhecida definição atribuída ao livro das sentenças de PAUlo (1.7.1), que os compiladores visigóticos recolheram na Lex Romana Visigothorum: "integri restitutio est redintegrande rei vel causa actio" ${ }^{159}$.

A definição retrata fielmente a transformação sofrida pelo antigo remédio pretoriano, a começar pela terminologia, com a substituição da tradicional expressão restitutio in integrum por integri restitutio. A nova expressão é encontrada em textos do IV e V séculos, compilados no Código Theodosiano (2.16.2) e no livro das sentenças de PaUlo ${ }^{160}$.

158. Ver a respeito o verbete Appello, de autoria de Orestano, na Enciclopedia del Diritto, v. 2, p. 709.

159. GuSTAVUS HaENEL, Lex Romana Visigothorum, Scientia Verlag Aalem 1962 , p. 344 .

160. Ver os textos e os magistrais comentários de RAGGI, em La Restitutio, cit., p. 250 e segs. 
A transformação da restitutio in integrum em integri restitutio, segundo CERVENCA ${ }^{161}$, não é, por certo, devida ao acaso mas, antes o índice da modificação verificada na própria estrutura do instituto. Com a nova terminologia não se alude, como no direito clássico, a uma restituição que se concede em favor de uma pessoa, no sentido de ser ela restituída por inteiro à situação anterior, porém, a uma restituição do inteiro, vale dizer, que tem por objeto uma coisa a ser restituída na sua integridade.

$\mathrm{Na}$ definição do instituto a nova expressão serve para ressaltar aquilo que é o seu efeito material, a restituição de uma coisa, que na idade clássica, no sistema do Ordo, se persegue com um meio conceitualmente distinto da r.i.i., a actio rescissoria, não obstante, em muitos casos esta ser conseqüente àquela.

A mudança terminológica representa, por isso, o índice de uma transformação substancial, pela qual a r.i.i. e actio rescissoria aparecem já confundidas, e, portanto, à própria r.i.i. vem a competir a qualificação de meio apto para operar a restituição material.

Tal transformação ter-se-ia iniciado no reinado de DioCLECIANO a partir do qual o direito romano começa a se distanciar de sua elaboração clássica, e, sob a influência de múltiplos fatores, passa a assimilar novos institutos e a inserir no sistema novas normas, que eliminaram e substituem as antigas ${ }^{163}$.

No reinado de JUSTINIANo, opera-se uma reação no sentido da revalorização do antigo remédio pretoriano, com o restabelecimento de sua específica finalidade processual de restituir as partes à sua situação anterior, mediante a rescisão do ato considerado contrário às normas da eqüidade, muito embora seu campo de aplicação tenha sido limitado às questões do interesse dos menores, $\Theta$ dos maiores no caso de ausência, segundo os termos da constituição de 531 (Cod. 2.52.7).

A r.i.i. mantém-se, então, como um instituto predominantemente processual, dotado de eficácia constitutiva, que produz sempre a rescisão do ato ou do julgamento questionado;

161. Cervenca, Studi Vari, cit., p. 142; Fabbrinni op. cit., p. 228.

162. Cervenca, op. cit., loc. cit.

163. Emilio Albertario, Introduzione Storica allo studio del Diritto Romano Giustinianeo, Milão 1935, p. 86. 
um remédio extraordinário em benefício dos menores e dos ausentes no iudicium rescissorium.

Entre a r.i.i. da idade clássica e a do direito justinianeu coloca-se importante diferença quanto ao método de sua atuação.

Naquela, uma vez concedido o auxilium extraordinarium, as partes eram restituídas à sua situação anterior como se o fato não tivesse ocorrido, o que se dava em virtude da ficção de ter-se realizado um salto "indietro nel tempo", ou seja, para o restabelecimento da situação anterior fingia-se que o ato ou fato não havia ocorrido.

Semelhante concepção é incompatível com a mentalidade da sociedade imperial do Baixo Império, particularmente do tempo de JUstiniano.

Em um fragmento do $\mathrm{V}$ século encontra-se a seguinte afirmação a propósito das actiones in factum: "Et in factum actio non consumitur, quia quod factum est infectum fieri non potest" 164, que revela a adoção de uma atitude realista em relação aos fatos geradores de direito.

$\mathrm{O}$ princípio é agasalhado no direito justinianeu. Na Novela 97, que dispõe sobre a igualdade dos dotes e das doações propter nuptias, o Imperador afirmou: "quod enin factum est, infectum manere impossibile est” (cap. I).

Essa radical mudança teria de se refletir no instituto da restituição, mediante a superação da velha e até certo ponto ingênua ficção de que o fato não teria ocorrido, para admitir-se realisticamente que o fato ocorreu, mas não podia produzir efeitos jurídicos por violar os princípios da eqüidade, pelo que não podia subsistir.

No direito justinianeu a reintegração das partes em sua situação anterior, por força da r.i.i., opera-se com a rescisão do ato ou do julgamento questionado, o qual é simplesmente anulado por motivo de eqüidade.

A anulação do julgamento tem como pressuposto a sua existência e validade formal, porquanto o julgamento nulo, por defeito processual, continuou sendo considerado juridicamente inexistente.

A marcante diferença entre a restitutio clássica e a do direito justinianeu serve de fundamento para a caracterização

164. Fragmenta Augustodunesia 111 - o texto integral é reproduzido em Textes de Droit Romain de Girard et Senn. $7 .^{\mathbf{a}}$ ed., p. 238. 
desta última como remédio extraordinário de revogação de sentença, com eficácia constitutiva, uma vez que a restitutio pretoria não revogava propriamente a sentença, porém restabelecia para as partes a situação anterior, como se o julgamento não tivesse sido proferido, prevalecendo somente a sentença que viesse a ser pronunciada posteriormente no iudicium rescissorium.

Tendo em vista sua finalidade rescisória HENRI AUBERT ${ }^{165}$ definiu-a: "L'annulation, prononcée par le magistrat compétent, pour des motifs spécialement déterminés, d'une sentence pleinement valable au regard du droit mais causant un préjudice contraire à l'équité; annulation qui a pour effet de rétablir les parties dans les droits qu'elles avaint respectivement avant l'instance".

13. No Império o benefício da r.i.i. concedido aos menores é reconhecido por analogia em favor da res publica (Dig. 49.1.9; Cod. 1.50.1; 2.54.4; 11.30.3).

$\mathrm{Na}$ ampla e genérica expressão res publica entendeu-se estarem abrangidos o Estado, as circunscrições políticas e administrativas (províncias, cidades, comunas) e o fisco ${ }^{166}$.

$O$ fundamento invocado para justificar a extensão do benefício era que, a exemplo dos menores, essas entidades tinham necessariamente de ser representadas por terceiros, o que as expunha ao risco de serem lesadas.

Para SAVIGNY ${ }^{167}$, o fundamento não parece adequado, porquanto, a seu ver, existe verdadeiramente mais analogia entre a situação dessas entidades com a dos ausentes do que com a dos menores.

Nos textos, entretanto, a referência analógica à situação dos menores é expressa: "Respublica minorum iure uti solet, ideoque auxilium restitutionis implorare potest" (Cod. 2.54.4).

Depois de trezentos anos de perseguições o cristianismo alcança em Roma a posição singular de religião reconhecida e prestigiada com a conversão de Constantino, que, em se-

165. AUBERT, op. cit., p. 13.

166. Augusti HeLlfeld, Jurisprūidentia Pandectarum, cit., § 465, p. 150; Gluck, op. cit., v. 4, § 465, p. 205; SAVIGNY, op. cit., v. 7, p. 202; Vita Levi, De Restitutione, cit., p. 113; B. WINDSCHEID, Diritto delle Pandette, trad. de FADDA e Bensa, Turim 1902, v. I, \& 117 p. 464; G. BIANCHINI, verbete Restitutio in Integrum, cit., p. 202.

167. SAVIGNY, op. cit., p. 204 e 234. 
guida ao célebre Edito de Milão (313) ${ }^{168}$, passa a conceder à Igreja importantes privilégios, notadamente na esfera da jurisdição episcopal (Cod. Th. 1.27.1).

A orientação religiosa do Império e da legislação torna-se mais decidida e mais ampla com os sucessores de CoNsTANTINo, salvo no interregno paganizante do curto reinado de JULIANo o Apóstata, voltado para a restauração do culto das divindades segundo as tradições romanas, quando, então, muitos dos privilégios são abolidos.

TEODosio I encarrega-se não só de restabelecer os antigos privilégios como de acrescentar outros. Em 380, Graciano e TEODOsIo promulgam a famosa lei conhecida como o Edito de Tessalônica, dirigido a todos os povos do Império, determinando-lhes que abracem a fé cristã, "Cunctos populos, quos clementiae nostrae regit imperium, in tali volumus religione versari, quam divinum Petrum Apostolum tradidisse Romanis". . (Cod. Th. 16.1.2; Cod. J. 1.1.1), que se torna a religião oficial do Estado ${ }^{169}$.

À igreja, por motivo de sua condição, os Imperadores outorgam uma série de prerrogativas e isenções, que a colocam em posição privilegiada ao lado do Estado. A vasta legislação a respeito foi compilada no Livro 16 do Código Teodosiano, nas Novelas Post-Teodosianas, nos 13 primeiros Títulos do Livro Primeiro do Código de Justiniano e em várias Novelas desse Imperador.

Presume-se que, a partir do reinado de TEodosio i no oriente e GRACIANo no ocidente, a Igreja, tal como o Estado, gozasse do benefício da r.i.i. em igualdade de condições com os menores. Todavia, não se encontra naqueles repertórios um texto específico sobre o reconhecimento do direito àquele benefício.

O Imperador ZENON, em 476, empenhado em reimplantar o cristianismo ortodoxo como religião oficial e em restituir a Igreja ortodoxa de Constantinopla à sua proeminente posição anterior, determinou por uma constituição especial o restabelecimento de todos 0 s direitos e privilégios que se conhece que a Igreja teve antes do advento da tirania do usurpador BAsílico,

168. Cf. JeAN GAUDEMET, L'Église dans L'Empire Romain, IV - V siécles, Paris 1958, p. 9 e segs. e Institutions de L'Antiquité, Paris 1967, p. 690; Biondo BIONDI, Il Diritto Romano Cristiano, Milão 1952, v. I, p. 119 e segs.

169. Sobre o Edito de Tessalônica, ver BroNDI, op. cit. v. I, p. 304 e segs. 
que os havia abolido, os quais regiam sobre a fé da religião ortodoxa e estado das santíssimas igrejas. (Cod. V 1.2.16).

Estabelece a constituição: "Decernimus, ut antiquatis ac infirmatis funditus his, quae contra ipsum orthodoxae religionis Deum quodam modo facta sunt, in integrum restituantur universa, et ad suum ordinem revocentur". .

Segundo CeRvencA ${ }^{170}$, essa constituição de ZENON é a única, em todo o $\mathrm{V}$ século, em que aparece uma referência direta à r.i.i., porém, no seu entender, a constituição alude à restitutio com o significado substancial de efeito da reintegração, e não como meio técnico processual.

É no Direito Canônico, consolidado em plena Idade Média, no apogeu da autoridade jurídica da Igreja, que o princípio é proclamado explicitamente.

Nas Decretais de GREGorio IX, de 1234, o Título XLI do Livro I, é inteiramente dedicado à "de integrum restitutione", de que trata também o cap. XI, do Tit. 13 do Livro III.

Posteriores coleções canônicas introduziram algumas modificações tendentes a reforçar o instituto, tais como as constantes dos capítulos I e II, do Título XXI do Livro I, do Liber Sextus Decretalium, de BoNIFACIo viII, de 1298, e do cap. único do Título XI do Livro I, das Clementinarum, de Clemente V, de 1314.

O fundamento invocado era o mesmo do direito romano: "Restituitur Ecclesia laesa propter negligentiam Procuratorii qui iura Ecclesiae non produxit" (Decretais. L.I.T.XLI, cap. II) .

Tal como no direito imperial em que, em circunstâncias excepcionais, o Imperador concedia a restituição contra sua própria sentença (Dig. 4.4.18 $\S 1^{\circ}{ }^{\circ}$ ), no Direito Canônico, também, a restituição podia ser concedida contra sentença proferida pelo Papa: "Etiam contra sententiam Papae restituitur Ecclesia” (Dec. ibidem cap. V).

14. Na Monarquia absoluta firma-se o princípio que a sentença proferida contra o direito proclamado pelas leis e constituições imperiais era nula e não transitava em julgado, podendo a nulidade ser reconhecida e declarada sem necessidade da impugnação da sentença pelo recurso ordinário da apelação.

170. Cervenca, Studi Vari, cit., p. 162 e nota 79. 
Tal princípio, ao que parece, teria sido formulado no Principado, na idade dos Severos, uma vez que é referido nos escritos de jurisconsultos daquela época (MACRo, Dig 49.8.1 § 2; Modestino, Dig. 49.1.19; Callistrato, Dig. 42.1.32) e numa constituição do Imperador AlEXANDRE SEVERo (Cod. 7.64.2), não sendo encontrado nos escritos e nas constituições dos jurisconsultos e Imperadores precedentes ${ }^{171}$.

O princípio está em consonância com o espírito desse período histórico, cuja linha evolutiva assinala a passagem do Principado para a Monarquia absoluta.

$O$ fundamento desse novo motivo de invalidade da sentença era político ${ }^{172}$, com o objetivo de impor a supremacia das normas jurídicas estabelecidas pelos Imperadores e assegurar sua observância pelos órgãos judicantes em todo o império.

No regime do Ordo, os diferentes motivos de nulidade da sentença eram atinentes, tão-somente, aos pressupostos processuais que o ordenamento exigia para que se pudesse constituir, desenvolver e concluir um processo com uma sentença válida ${ }^{173}$.

Nesse período os motivos de nulidade da sentença não diziam respeito, jamais, à intrínseca injustiça do julgado, à inobservância de preceitos do direito substancial, ou ao mérito da lide decidida.

Em seu rígido formalismo o processo só conhece a antítese validade - inexistência, de maneira que a existência do julgado, como tal, está condicionada à validade formal da sentença. Se a sentença fosse formalmente inválida, dizia-se não existir julgamento.

A propósito do valor da palavra condemnatum, ULPIANo escreveu expressivamente em seus Comentários ao Edito, dever-se entender por condenado aquele que o foi em processo regular por sentença válida, porque se a sentença é nula por qualquer razão, deve-se dizer que não tem lugar o termo condenação: "Condemnatum accipere debemus eum, qui rite condemnatus est, ut sententia valeat; ceterum si aliqua ratione

171. ORESTANo, L'Appello, cit., p. 278.

172. Orestano, op. cit., p. 277; ver, também, Calamandrei, La Cassazione, cit., v. I, p. 55 a 58.

173. Orestano, op. cit., p. 99; Calamandrei, op. cit., p. 21. 
sententia nullius momenti sit, dicendum est, condemnationis verbum non tenere. (Dig. $42.1 .4 \S 6$ ).

No Principado, no regime da cognitio extra-ordinem, ao lado dos motivos formais de invalidade da sentença, que acarretavam a inexistência do julgado, motivos que vinham do sistema do Ordo iudiciorum privatorum e subsistiram no direito justinianeu, foi introduzido um outro, de natureza substancial, concernente ao erro de direito traduzido na inobservância das normas estabelecidas nas leis e nas constituições imperiais.

A sentença proferida contra ius constitutionis passou, também, a ser considerada non ulla, isto é nenhuma.

A introdução deste novo critério ampliou a esfera da nulidade das sentenças, alçando a inobservância das normas editadas pelos Imperadores ao nível das regras processuais sobre a validade dos julgamentos, que o espírito formalista do direito romano clássico considerava como garantia do cidadão para a perfeita distribuição da justiça.

Estrutura-se, então, a fundamental distinção entre ius litigatoris e ius constitutionis, que vai servir de base para a aplicação prática do princípio, em razão da impugnabilidade da sentença.

$O$ vencido por uma sentença nula não tinha necessidade de apelar, porque, não transitando em julgado por ser considerada juridicamente inexistente, podia ser revogada a qualquer tempo, quando o vencedor intentasse fazê-la valer em juízo.

Diversa era a situação do vencido, quando a sentença houvesse julgado contra o seu direito, não contra o direito das leis imperiais, impendendo-lhe apelar para que não transitasse em julgado.

A distinção foi claramente exposta por MACRo: "Item quum contra sacras Constitutiones iudicatur, appellationis necessitas remittitur. Contra Constitutiones autem iudicatur, quum de iure Constitutionis non de iure litigatoris pronuntiatur,... Quodsi... de iure litigatoris pronuntiasse intelligitur; quo casu appellatio necessaria est”. (Dig. 49.8.1 § 2).

Quanto à invalidade da sentença proferida contra o direito objetivo, encontra-se em MoDESTINo este preciso ensinamento: "Si expressim sententia contra iuris rigorem data fuerit, valere non debet; et ideo et sine appellatione causa denuo induci potest. Non iure profertur sententia, si specialiter contra leges, 
vel Senatus consultum, vel Constitutionem fuerit prolata". (Dig. 49.1.19).

O princípio que a sentença nula não transitava em julgado e podia ser rescindida sem necessidade da apelação foi acolhido na legislação de JUSTINIANo, que lhe consagrou dois sugestivos títulos: "Quae Sententiae sine Appellatione Rescindantur" (Dig. 49.8) e "Quando provocare non est necesse" (Cod. 7.64).

Pressuposto da apelação contra a injustiça da sentença bem como da restitutio in integrum contra o julgado iníqüo, era tratar-se de sentença válida, quando sua impugnação é necessária, no primeiro caso para não transitar em julgado, e no segundo para rescindi-la, mesmo depois de se ter constituído res iudicata.

A sentença nula, non ulla nenhuma, não tinha existência jurídica, não ocorrendo a necessidade de ser revogada.

15. Ao longo da história do processo civil romano, manteve-se inalterado, durante todos os seus períodos, o princípio que a sentença resultante de julgamento nulo era considerada como juridicamente inexistente.

Por esse motivo não constituía res iudicata e sua existência podia ser negada em juízo, a qualquer tempo, independentemente de prévia revogação por qualquer dos meios ordinários ou extraordinários preordenados para esse fim.

Para obter a declaração da nulidade do julgamento e conseqüente ineficácia da condenação, ao vencido bastava aguardar que o credor iniciasse o procedimento da correspondente actio iudicati para, perante o Pretor, na fase in iure, contestar a existência do julgado mediante a infitiatio, correndo o risco de ser condenado no dobro do pedido se a sentença exeqüenda fosse a final julgada válida, risco esse que desapareceu no direito justinianeu.

No período post-clássico, sem dúvida, o vencido podia, também, antecipar-se à actio iudicati e tomar a iniciativa de promover a declaração judicial da nulidade do julgamento, instaurando contra o credor 0 processo da revocatio in $d u$ plum ${ }^{174}$.

Contra o julgamento nulo, entretanto, sempre se entendeu desnecessário o recurso da apelação que tinha por pressuposto

174. Cf. a primeira parte deste trabalho, Rev. Fac. Dir. da USP, 1977, v. $72,1 .^{\circ}$ f., p. 371 . 
a existência de uma sentença válida, isto porque, a finalidade da apelação era de obter novo julgamento sobre a mesma causa, sendo para tanto permitida a argüição de novas exceções e a apresentação de novas provas no juízo ad-quem.

O emprego da apelação, como gravame de nulidade, conflitava abertamente com o escopo daquele recurso, uma vez que não se destinava a promover o reexame da lide, em segunda instância, para nova decisão.

Não obstante a anomalia, o fato de se encontrarem nas fontes tantos e tão incisivos textos a propósito da inutilidade do uso da apelação contra julgamentos nulos, parece demonstrar que semelhante praxe estaria se tornando comum, e, assim, esses textos destinavam-se a pôr em evidência a descorrelação entre o remédio técnico e o fim pretendido, porquanto a nulidade da sentença equivalendo à inexistência da condenação, prescindia de novo julgamento em segunda instância.

No estudo que dedicou a esse particular aspecto da impropriedade do emprego da apelação contra julgamentos nulos, LUIGI RAGGI ${ }^{175}$ arrolou quatro textos do Digesto $(2.12 .1 \S 1$; $49.1 .19 ; 491.23 \S 1 ; 49.8 .1 \S 2)$ oito textos do Código $(7.64 .1 ; 7.64 .2 ; 7.48 .2 ; 7.44 .1 ; 764.4 ; 7.64 .5 ; 7.64 .6$; 7.64.7) e um do Código Teodosiano (4.17.1), para concluir que a necessidade, em diferentes momentos históricos, de chamar a atenção para a inutilidade da apelação contra julgamentos nulos, leva a admitir-se que existia, de fato, a tendência generalizada de uma praxe oposta. Evidentemente, atrás desta numerosa série de testemunhos, pertencentes a épocas diversas, devia haver uma situação de fermentação a suscitar seguidamente a necessidade de determinações normativas sobre o uso adequado dos instrumentos processuais.

Como exemplo do emprego efetivo da apelação em casos em que o julgamento era nulo, costumam ser citados dois textos de PAULo, ao que parece referentes à mesma hipótese (Dig. 10.2.41 e 37.14.24) e um de Modestino (Dig. 42.1.27). VASSALLI ${ }^{176}$, examinando brevemente a questão, depois de lembrar que o direito clássico aplicava largamente o conceito da nulidade absoluta das sentenças, e que o processo ordinário, no qual normalmente era excluída a apelação contra a sentença do iudex, explicava bem essa tradição jurídica, assevera,

175. RAGGI, Studi sulle impugnazione, cit., p. 25, 26.

176. Filippo Vassalli, Studi Giuridici, v. III-I, Stuidi di Diritto Romano, Milão $1960, \mathrm{p}, 391,392$. 
em seguida, que a tradição não se mantém igualmente conforme, no ordenamento burocrático da administração da justiça, na idade post-clássica e justinianéia. "La sfera dell' appello devette estendersi e corrispondentemente restringersi quella della nullità assoluta" E, em abono de seu entendimento, invoca o texto de Modestino (Dig. 42.1.27) "che ha sempre affaticato gli interpreti”, como ele próprio reconhece.

O tema despertou desde logo a atenção dos romanistas.

RAGGI ${ }^{177}$, que se deteve longamente na apreciação da opinião de VASSALLI, assinalou, com rigorosa interpretação do texto, que MoDEstino se refere a uma apelação que é inoperante por não terem sido respeitados os cânones legais, não, porém, porque aplicada a uma sentença nula. Daí a admitir-se que, naquele caso, a propositura da apelação implicava no reconhecimento da sentença e, por conseguinte, na sanação da sua nulidade, o passo é muito longo e a doutrina há muito já repeliu semelhante hipótese ${ }^{178}$.

Ocorre, também, que em outra passagem o mesmo MoDEsTINo, dissertando sobre a nulidade da sentença proferida contra o direito expresso, afirmou: "Si expressim sententia contra iuris rigorem data fuerit, valere non debet; et ideo et sine appellatione causa denuo induci potest. Non iure profertur sententia, si specialiter contra leges vel senatus consultum vel constitutionem fuerit prolata, unde si quis ex hac sententia appellaverit et praescriptionem summotus sit, minime confirmatur ex hac praescriptione sententia, unde potest causa ab initio agitari". (Dig. 49.1.19)

Abstraindo-se das sensiveis interpolações, que têm sido apontadas pelos romanistas que examinaram esse texto, pergunta-se: seria possível, sem mais nada, deduzir que a opinião de Modestino, acolhida em 42-1-27, constituía superação do conceito da nulidade como inexistência, afirmado em 41-1-19 pelo mesmo jurisconsulto?

A indagação é pertinente e relevante.

O ilustre romanista ${ }^{179}$ que a formulou respondeu-a negativamente, após exaustivo estudo da questão, em cuja conclusão sustenta que se deve negar a existência de contradição entre os dois textos.

177. RAGGI, op. cit., p. 78 a 104 .

178. Calamandrei, La Cassazione, cit., v., I, p. 75.

179. RAGGI, op. cit., p. 84. 
A diversidade de soluções que eles acolhem é nada menos que a conseqüência da diversidade dos respectivos casos. Por conseguinte, o texto de 42.1.27 não derroga inteiramente a concepção da nulidade como inexistência, mas põe em evidência um preciso limite, sob o perfil instrumental da sua aplicabilidade.

Assim, a seu ver, é inútil insistir sobre o desmentido que disto resulta para a tese da transformação dos motivos de nulidade em motivos de apelação ${ }^{180}$.

Quanto aos dois textos de PaUlo (Dig. 10.2.41 e 37.12.24) que dizem respeito ao mesmo caso de apelação interposta contra uma divisão hereditária ${ }^{181}$, na qual o iudex teria ultrapassado o limite de sua competência, incluindo na partilha bens que por sua natureza, como os créditos de obrigação alimentar, estavam subtraídos ao iudicium familiae erciscundae (Dig. 10.2.2 § 5. "In hoc iudicium etsi nomina non veniunt"...) e, por esse motivo, seria nula, a doutrina há muito tempo vem se ocupando com esse caso, não só para precisar o alcance e o exato significado dessa hipótese de apelação (instituto do processo da cognitio extra-ordinem) contra a decisão de um iudex, na actio familiae erciscundae, operando segundo o processo formulário do Ordo, como, também, para situá-lo no âmbito do direito hereditário romano e do iudicium familiae erciscundae, tendo em vista as limitações desse juízo especial estabelecidas em diversos textos (Dig. 10.2.25 § $1 ; 10.2 .44$ $\S 3 ; 10.2 .45 ; 10.2 .49)$.

Os dois fragmentos de PAULo, entre outras implicações que têm sido examinadas por inúmeros autores antigos e modernos, ${ }^{182}$ prestam-se particularmente para ilustrar, com um caso concreto, a possibilidade de ocorrência de nulidade parcia] do juízo divisório e, assim, de sua reforma parcial, mediante impugnação parcial.

Segundo ORESTANO ${ }^{183}$, a possibilidade de impugnação parcial, de modo geral, teria sido reconhecida por UlPIANo, quando escreveu que em nada prejudica ao apelante não ter indicado no libelo de que parte da sentença apelou (Dig.

180. RAGGI, op. cit., p. 95 .

181. Cesare Sanfilippo, Pauli Decretorum Libri Tres, Milão 1938, p. 31-32.

182. Ver a indicação desses autores e obras feita por RAGGI, op. cit., p. 29, nota 9.

183. Orestano, L'Appello, cit., p. 289. 
49.1.13). E a questão examinada pelo jurisconsulto PAULo é, então, um exemplo típico de impugnação parcial ${ }^{184}$.

Vistos por esse ângulo, os fragmentos de PAULo não se prestam para infirmar o princípio da desnecessidade da apelação contra o julgamento nulo, quando a nulidade fosse parcial e houvesse necessidade de ser impugnada a parte válida do julgado para não se tornar res iudicata.

Ademais, como observou CALAMANDREI ${ }^{185}$, o caso a que se referem esses textos é antes de jurisdição voluntária que de jurisdição contenciosa.

16. Questão vivamente controvertida, a que os estudiosos têm proposto diferentes soluções, é a da possibilidade da existência de um meio autônomo de impugnação da sentença eivada de nulidade, diverso da apelação, quando a nulidade não fosse evidente e ao vencido, que tinha interesse em vê-la reconhecida, faltasse um remédio idôneo para esse fim.

Em razão da específica finalidade da apelação, de promover em segunda instância novo julgamento da lide, é fora de dúvida que tal remédio ordinário era inteiramente inadequado para se obter tão-somente a declaração do vício da sentença.

Encontram-se nas fontes dois textos nos quais se depara o emprego de uma expressão que, segundo parte da doutrina, servia para designar um meio autônomo de impugnação do vício de nulidade da sentença.

Trata-se do vocábulo querela, utilizado por MARCELo no fragmento reproduzido por JULIANo: "Marcellus notat: si per dolum sciens falso aliquid allegavit, et hoc modo consecutum eum sententia Praetoris liquido fuerit approbatum, existimo debere iudicem querelam rei admittere (Dig. 5.1.75), que é empregado, também, pelo Imperador GORDIANO, num rescripto do ano 239: "Ab eo iudicato recedi non potest, quod vobis absentibus et ignorantibus atque indefensis dicitis esse prolatum, si, ubi primum cognovistis, non illico de statutis querelam detulistis" . (Cod. 7.43.3)

Alguns autores fundamentam-se na interpretação desses dois textos para sustentar que se deva entender a querela como recurso dirigido a declarar o vício da sentença, de que se trata,

184. Orestano, op. cit., p. 290 , nota 1.

185. Calamandrei, La Cassazione, cit., v. I, p. 75, nota 2. 
o qual é assim designado com uma palavra de significado genérico e não técnico.

ANTôNio Costa ${ }^{186}$, em amplo estudo sobre o tema, informa ser essa a opinião de WETZELL, que transcreve ipsis litteris no original, aduzindo que, anteriormente, GONNER e HEFFTER em seus livros sobre o processo civil romano e alemão, publicados em 1805, 1825 e 1834, já sustentavam a origem romana dá querela nullitatis, entendendo HEFFTER, inclusive, que a distinção entre causa de nulidade sanável e insanável já era admitida no direito justinianeu, com o que não concorda MiTTEIs.

Em posição antagônica SKEDL, seguindo a interpretação de RENAUD, entende que as passagens invocadas por WETZELL, em abono da origem romana da querela nullitatis, atinham-se preferivelmente à restitutio in integrum ${ }^{187}$.

No mesmo sentido a doutrina professada por BETHMANN HOLLWEG ${ }^{188}$, para quem a querela nullitatis, surgida na legislação estatutária italiana do século XIII, não se encontraria em conexão alguma com os institutos jurídicos do processo romano ("eine querela nullitatis ist dem römischen Recht unbekannt") pelo que, o vocábulo querela, utilizado por MARCELo, tem o significado de uma queixa por dolo da parte contrária e de solicitação da restitutio in integrum ${ }^{189}$.

Segundo WENGER ${ }^{190}$, não obstante as diferentes interpretações apresentadas, ainda permanece obscuro o ponto sobre que classe de querela é esta, podendo considerar-se como certo que se trata de uma imputação à validez jurídica da sentença.

ORESTANo ${ }^{191}$, igualmente, vê na palavra querela, empregada pelo Imperador GoRDIANO, uma expressão vaga, que pode significar o ato de apelar, como pensam APELT, STEINWENTER e outros, mas, talvez, mais provavelmente está a indicar uma qualquer queixa que fosse suficiente para demonstrar a não aquiescência à sentença. $O$ que pode exprimir atenuação da necessidade da apelação contra semelhante sentença.

186. ANTônio Costa, La nulitá della sentenza e la "querela nullitatis" nella storia del processo italiano, na Rivista Italiana per le Cienze Giuridiche, 1916 , v. 47 , p. 219 e segs.

187. Antônio Costa, La nullitá, cit., p. 229, nota 1.

188. Bethmann-Hollwe, Der Römische Civilprozess, v. II, p. 726, citado e transcrito por A. Costa, op. cit., p. 228, nota 1.

189. Bethmann-Hollweg, op. cit., v, II, p. 726, citado por Wenger, Actio Iudicati, trad. cast. Ed. EJEA, 1954, p. 215, nota 34 .

190. Wenger, Actio Iudicati, cit., loc. cit.

191. OREstano, L'Appello, cit., p. 359. 
Aliás, em dois fragmentos de PAULO, a propósito da aprovação dos fiadores pelo árbitro e da possibilidade de recorrer de seu julgamento para o Juiz competente, a doutrina entreviu a equivalência da função da querela, mencionada pelo jurisconsulto ("Si ab arbitro probati sunt fideiussores, pro locupletibus habendi sunt, quum potuerit querela ad competentem iudicem deferri" Dig. 2.8.10) à da apelação, que, entretanto, é declarada desnecessária para a correção da sentença naquela hipótese ("Quaesitum est, in arbitros, qui ad fideiussores probandos dantur, an appellare liceat; quamvis hoc casu et sine appellatione quidam putent ab eo, qui eum dedit, sententiam eius corrigi posse" Dig. 49.2.2).

O exato significado da querela e de sua verdadeira função no processo da cognitio extra ordinem constituem, ainda hoje, como salientou WENGER, ponto obscuro que os romanistas não lograram dilucidar.

Ante a imprecisão dos textos só lhes restou a elaboração de hipóteses baseadas na interpretação que se afigurou mais adequada às respectivas conjecturas doutrinárias.

Para alguns, meio autônomo de argüição do vício de nulidade de que padeciam determinadas sentenças, em casos em que não coubesse apelação, atuando mediante simples reclamação; para outros, queixa contra o dolo do adversário, ou contra a sentença proferida na ausência do réu, configurando em ambas as hipóteses a impetração da restitutio in integrum, que era o remédio cabível para esses casos.

Ao que parece, na Monarquia absoluta, a querela teria sido mesmo um meio autônomo de impugnação de atos judiciais, distinto da apelação, segundo se depreende de uma constituição do ano 323, recolhida no Código Teodosiano, 11.30.12, cujo texto, entretanto, inexplicavelmente, ainda não foi examinado, nem mencionado sequer, pelos autores que atribuem à querela essa função.

Trata-se de duas questões: a primeira, de recusação do magistrado nomeado, esclarecendo o texto que o ato de recusa se chamará querimônia (reclamação, queixa) e não apelação pois o nome apelação deve ser empregado em casos mais importantes; na segunda, se o nomeado para a cobrança das taxas sobre os mercados for acusado de injustiça, acrescenta 0 texto que, igualmente, este ato se chamará querela (sinônimo de querimônia) e não apelação. Por isso não devem ser observados os prazos das apelações, decidindo-se, pelo contrário, desde logo, as reclamações. 
"Si nominatus magistratus aliquis refragetur, non appellatio, sed querimonia hoc dicetur; appellationis enim verbum in maioribus rebus dici oportet.

Similiter et si ad exactionem annonarium nominatus de injustitia queratur, non appellatio sed querela hoc esse videbitur. Ideoque nec tempora appellationum servanda sunt, sed mox super hujusmodi querimoniis disceptandum". (Cod. Th. 11.30.12).

Ao contrário do que ocorre com os textos recolhidos no Digesto e no Código de Justiniano, nesta constituição do tempo de ConstANTINo as expressões são empregadas com suficiente clareza e precisão, de maneira a não deixar dúvida que a querela, como queixa contra nulidade ou injustiça de atos judiciais, era um remédio autônomo, distinto da apelação e da restitutio in integrum.

No que diz respeito ao problema histórico de encontrar-se na querela romana a origem da querela nullitatis, que floresceu no direito estatutário italiano, a opinião dos estudiosos está, também, dividida.

CALAMANDREI 192 afirma, incisivamente, que a querela nullitatis, instituto desconhecido do direito romano e do direito germânico, aparece na legislação estatutária italiana do século XII, desenvolve-se e toma forma na do século XIII, atinge sua plena maturidade na do século XIV; portanto, ela não pode dizer-se de origem romana, nem de oṛigem germânica, mas de pura formação italiana.

Perfilhando a doutrina sustentada por WETZELL, entende Antonio Costa ${ }^{193}$, que a utilização de um meio recursal, que não a apelação, contra a nulidade da sentença, não constituiria uma novidade do direito estatutário italiano do século XIII, e a querela nullitatis teria já algum germe e precedente nas fontes romanas; a influência germânica dever-se-ia atribuir não propriamente à gênese da querela, mas, antes à configuração e sua disciplina, como instrumento conhecido para provocar a atividade judiciária do magistrado analogamente à appellatio.

A constituição de 323 parece confirmar esse entendimento, embora ainda não tenha sido invocada pelos autores.

192. CalamandreI, La Cassazione, cit., v. I, p. 138.

193. A. Costa, La nullitá, cit., p. 229. 
17. Numa antiga, mas altamente conceituada história do Direito Romano ${ }^{194}$, está escrito, em síntese magistral, que a história da restitutio in integrum é a história da progressiva vitória da eqüidade sobre o rigor do direito, mas, infelizmente, dessa história não possuímos senão poucos pontos determinados.

$\mathrm{E}$, no último esboço histórico, traçado para servir de contribuição para a história do instituto, mesmo após a publicação de dezenas de estudos sobre o tema, aquela dificuldade permanece e é posta em realce pelo historiador contemporâneo.

FABBRINI ${ }^{195}$ inicia o seu trabalho com estas palavras: $\hat{E}$ muito difícil traçar as linhas de uma história da restitutio in integrum: seja porque as fontes - freqüentemente suspeitas de interpolações - não permitem seguir com segurança as vicissitudes do instituto em todas as épocas do direito romano; seja porque muitos argumentos têm sido descurados pela doutrina, e, como quer que seja, em conjunto não há ainda uma massa de contribuições parciais tão considerável para permitir o sucesso de uma tentativa de síntese.

A falta em nossa literatura de um estudo atualizado sobre o assunto, notadamente no que tange à apreciação da evolução histórica e dos aspectos controvertidos do instituto - uma vez que o livro de AlmeIDA OLIVEIRA ${ }^{196}$, único publicado entre nós, está totalmente superado pelas investigações posteriores - levou-nos a redigir este artigo, com a exclusiva preocupação de divulgar o resultado dos notáveis trabalhos publicados pelos modernos romanistas, podendo servir de guia bibliográfico para os estudiosos brasileiros que desejarem aprofundar o estudo do tema, indo além das simples anotações aqui reunidas.

O grande número de citações feitas justifica-se pela necessidade de documentar a extensa pesquisa realizada, em razão do fim a que se destina este trabalho no âmbito da Universidade.

\section{Arcadas, junho de 1978}

194. Padelletti-Cogliolo, Storia del Diritto Romano, 2. ${ }^{\text {a }}$ ed., Florença, 1886, p. 604.

195. Fabrizio FabBrini, Per la storia della "Restitutio in Integrum", em Labeo, 1967, p. 200.

196. A. De Almeida Oliveira, O Beneficio de Restituição in integrum, Rio de Janeiro, 1886. 